\title{
1 Female Assamese macaques bias their affiliation to paternal and
}

\section{2 maternal kin}

3 Running title: Kin biases in female Assamese macaques

4 Delphine De Moor* a,b,c,d Christian Roos ${ }^{b}$, Julia Ostner ${ }^{a, c, d}$ § \& Oliver Schülke ${ }^{a, c, d}$ §

5 a Department of Behavioural Ecology, University of Goettingen, Germany

6 b Primate Genetics Laboratory, German Primate Center, Leibniz Institute for Primate Research, Goettingen, Germany

7 c Leibniz-ScienceCampus Primate Cognition, Goettingen, Germany

8 d Research Group Primate Social Evolution, German Primate Center Leibniz Institute for Primate Research, Goettingen,

9 Germany

$10 \S$ Contributed equally as senior authors

11

12

13

14

15

16

17

18

* Corresponding author: Delphine De Moor

19 Kellnerweg 6, 37077 Göttingen, Germany

20

delphinedemoor@gmail.com

21

+491712009479

23 Word count: 7403 


\section{ABSTRACT}

25 Forming strong social bonds leads to higher reproductive success, increased longevity and/or increased infant survival in several mammal species. Given these adaptive benefits,

27 understanding what determines partner preferences in social bonding is important. Maternal relatedness strongly predicts partner preference across many mammalian taxa. Although paternal and maternal kin share the same number of genes, and theoretically similar preferences would therefore be expected for paternal kin, the role of paternal relatedness has received relatively little attention. Here, we investigate the role of maternal and paternal relatedness for female bonding in Assamese macaques (Macaca assamensis), a species characterized by a relatively low male reproductive skew. We studied a wild population under

34 natural conditions using extensive behavioural data and relatedness analyses based on pedigree reconstruction. We found stronger social bonds and more time spent grooming between maternal kin and paternal half-sisters compared to non-kin, with no preference of maternal over paternal kin. Paternally related and non-related dyads did not form stronger bonds when they had less close maternal kin available, however we would need a bigger sample size to confirm this. As expected given the low reproductive skew, bonds between paternal half-sisters closer in age were not stronger than between paternal half-sisters with larger age

41 differences, suggesting that age similarity was not the mechanism by which paternally related 42 individuals recognized each other. An alternative way through which paternal kin could get 43 familiarized is mother- and/or father-mediated familiarity.

\section{KEYWORDS}

45 kin discrimination; kin selection; nepotism; relatedness; social bonds 


\section{INTRODUCTION}

Many group-living animals show considerable variation in how they interact with other group members, forming strong relationships with only a few of their group mates and weak relationships with the rest of the group (Cameron, Setsaas, \& Linklater, 2009; Diaz-Aguirre, Parra, Passadore, \& Möller, 2018; Silk, Altmann, \& Alberts, 2006; J. E. Smith et al., 2010). As gregarious animals repeatedly associate with each other, the quality of their interactions can affect subsequent interactions, reinforcing the nature of their relationships (Hinde, 1976). Over time, such reinforcement leads to stable partner preferences in affiliation or social bonds (Silk, Cheney, \& Seyfarth, 2013). Investing time and energy in the formation and maintenance of these bonds might be adaptive in terms of inclusive fitness benefits, mutual benefits, or reciprocal exchanges (Clutton-Brock, 2009; Kummer, 1978). In several mammal species, individuals forming strong stable social bonds have a higher reproductive success, increased longevity and/or increased infant survival compared to more weakly bonded group mates (Brent, Chang, Gariépy, \& Platt, 2014; Ostner \& Schülke, 2018; but see Kalbitzer et al., 2017; Thompson \& Cords, 2018). Given this strong selective pressure, it is crucial to understand what factors underlie partner preferences in social bonding.

An important factor shaping adult partner preferences across most mammalian taxa is maternal relatedness (Archie, Moss, \& Alberts, 2006; Berman, 2015; Möller, 2012; Rossiter, Jones, Ransome, \& Barratt, 2002; Seyfarth \& Cheney, 2012; Silk, 2009; J. E. Smith, 2014; J. E. Smith et al., 2010). Because of the extended maternal care that is characteristic of most mammals, infants are closely spatially associated with their mother, which may promote the formation of strong social bonds that are maintained into adulthood (Broad, Curley, \& Keverne, 
2006). Females of many mammal species are philopatric; they spend their entire life in their natal group, surrounded by their maternal kin (Greenwood, 1980). In these species, mothers are imbedded into a social network of their own close maternal kin, and the strong motheroffspring bond in turn facilitates the development of bonds between close maternal kin, as infants are indirectly familiarized to their maternal siblings, aunts and grand-mother very early on (i.e. mother-mediated familiarity; Widdig, 2007). Maternal kin are readily available and easily recognizable, which could facilitate tolerance, affiliation and cooperation among maternally related females (Cords \& Nikitopoulos, 2015; Silk, 2009). More ultimately, a kin bias in affiliation towards maternal kin could arise due to the indirect fitness benefits individuals gain from cooperating with related individuals, according to kin selection theory (Hamilton, 1964).

79 Given that kin selection is blind to the origin of shared genes (Hamilton, 1964), one would expect a similar bias in affiliation towards paternal kin as towards maternal kin. A key issue, however, is paternal kin recognition (Strier, 2004; Widdig, 2007). In many mammal species,

82 females mate with more than one male during their fertile period (Jennions \& Petrie, 2000). Paternity is concealed in those species, which might hamper paternal kin recognition and, by

84 extension, the development of a bias towards paternal kin. Still, several mechanisms of paternal 85 kin recognition have been put forward. In species with a high male reproductive skew and a short alpha male tenure relative to the interbirth interval, infants that are born close in time 87 are likely sired by the alpha male and thus have a high chance of sharing the same father. As close-aged individuals grow up together, age proximity could be a potential mechanism 89 through which paternal kin are familiarized to each other (i.e. familiarity via age proximity; 
Altmann, 1979; Widdig, 2013). Alternatively, paternal kin could recognize each other through

91 mother- or father-mediated familiarity (Widdig, 2007). Mothers may mediate familiarity between paternal siblings directly, or infants could get familiarized through their common father if mothers affiliate with the father after birth. Similarly, fathers could mediate familiarity

94 if they affiliate with the mother, or if they provide paternal care to their offspring. Independent of familiarity, individuals could recognize their kin using phenotypic cues such as appearance, odour and vocalizations (i.e. phenotypic matching; Mateo, 2017; Widdig, 2007).

Primates have been particularly well studied on kin biases in sociality, because they live in stable, complex groups often containing both paternal and maternal kin, as well as non-related individuals (Chapais \& Berman, 2004; Silk et al., 2006). While maternal relatedness is generally

100 a strong predictor of bond formation (Silk, 2009; but see Candiotti et al., 2015), research on

101 paternal kin biases is still limited and the results are mixed (Berman, 2015). So far, paternal kin

102 biases in primates have only been reported in cercopithecines (Charpentier et al., 2012; Cords,

103 Minich, Roberts, \& Sleator, 2018; Lynch, Di Fiore, Lynch, \& Palombit, 2017; Silk et al., 2006;

104 Widdig, Nurnberg, Krawczak, Streich, \& Bercovitch, 2001), while no biases towards paternal kin 105 have been found in other primate taxa (Langergraber, Mitani, \& Vigilant, 2007; Perry, Manson, 106 Muniz, Gros-Louis, \& Vigilant, 2008; Wikberg, Ting, \& Sicotte, 2014).

107 Paternal kin biases are usually less pronounced than biases towards maternal kin (Charpentier 108 et al., 2012; Lynch et al., 2017; Silk et al., 2006; Widdig et al., 2001). This might reflect the lower 109 certainty of recognizing paternal kin compared to maternal kin (Berman, 2015). Additionally, 110 the presence and strength of paternal kin biases evidently depend on factors such as 111 demographic and mating patterns (Strier, 2004), like the availability of both maternal and 
112 paternal kin as potential bonding partners. For example, in two studies on the same population

113 of yellow baboons (Papio cynocephalus), paternal half-sisters were preferred to the same

114 extent as maternal half-sisters in a period when relatively few females had close maternal kin

115 available, while social bonds between paternal half-sisters were of intermediate strength

116 between maternal kin and non-kin in a later period when more females had close maternal kin

117 available (Silk et al., 2006; K. Smith, Alberts, \& Altmann, 2003). Individuals might thus form close

118 bonds with paternal kin to compensate for the absence of the preferred close maternal kin (Silk

119 et al., 2006).

120 Male reproductive skew is another major influence on paternal kin biases, determining the

121 availability of paternal kin and the likelihood for individuals born close in time to be paternally

122 related and thus the reliability of age proximity as a proxy for paternal relatedness (Altmann,

123 1979). It should be noted that familiarization with paternal kin via age similarity has been

124 questioned on theoretical grounds (Langergraber, 2012). While seasonal reproduction should

125 favour familiarization via age similarity because infants grow up together, increased seasonality

126 also decreases monopolization potential and thus reproductive skew among males, reducing

127 the chance that age mates are paternal kin. Kin biases towards paternal kin are stronger within

128 than between age cohorts in some species (yellow baboons: Silk et al., 2006; rhesus macaques

129 - Macaca mulatta: Widdig et al., 2001) but not in others, even though paternity concentration

130 in the alpha male is rather high (mandrills - Mandrillus sphinx,, alpha male skew: 76.2\%;

131 Charpentier, Peignot, Hossaert-McKey, \& Wickings, 2007; blue monkeys - Cercopithecus mitis,

132 resident male skew: 61\%; Cords et al., 2018). 
133 Here, we study kin biases in a population of Assamese macaques (Macaca assamensis) under

134 natural conditions, combining longitudinal behavioural data with genetic analyses of

135 relatedness based on pedigree reconstruction. Assamese macaques have a relatively low

136 reproductive skew (29\% alpha male paternity: Sukmak, Wajjwalku, Ostner, \& Schülke, 2014),

137 and a relatively long alpha male tenure relative to the interbirth interval, with males often being

138 able to keep their alpha position for consecutive mating seasons (Ostner, Vigilant, Bhagavatula,

139 Franz, \& Schülke, 2013). Familiarization of paternal kin through age proximity is thus unlikely.

140 Still, because of the long male tenure, many individuals might have paternal kin available in the

141 group, necessitating even more so to distinguish the few paternal kin from the many non-kin.

142 We predict (1) that, like in several other cercopithecine and mammal species, adult females

143 bias their affiliation towards maternal kin, (2) that affiliation is also biased to paternal kin, with

144 intermediate bond strength between maternal kin and non-kin, (3) that age proximity does not

145 affect bond strength between paternal kin, and (4) that paternal kin form stronger social bonds

146 when either one or both of the partners have few close maternal kin available, to compensate

147 for the lack of preferred maternally related bonding partners. 
MATERIAL AND METHODS

\section{Study site and study population}

151 We studied a population of fully habituated Assamese macaques ranging in their natural habitat

152 at the Phu Khieo Wildlife Sanctuary in north-eastern Thailand (PKWS, $16^{\circ} 05-35^{\prime} \mathrm{N} \& 101^{\circ} 20-$

$\left.15355^{\prime} \mathrm{E}\right)$. Part of the more than $6500 \mathrm{~km}^{2}$ interconnected and well-protected Western Isaan forest

154 complex, the sanctuary covers an area of $>1600 \mathrm{~km}^{2}$, with elevations ranging from 300 to 1551300 m above sea level (Schülke, Pesek, Whitman, \& Ostner, 2011). The pristine forest is

156 composed of dense, dry evergreen vegetation with patches of bamboo forest and harbours a 157 diverse community of large mammals and predators (Borries, Larney, Kreetiyutanont, \& Koenig, 158 2002).

159 This study is part of a long-term research project on this population of Assamese macaques. All

160 individuals could be reliably identified based on natural variation in appearance. We collected

161 data on one group in $2007 / 2008$ and $2010 / 2011$, on two groups in $2013 / 2014$, and on four 162 groups in 2015/2016 and 2016/2017. Each study period captured at least one year, including

163 the mating season from October to February and the non-mating season from March to

164 September (Fürtbauer, Schülke, Heistermann, \& Ostner, 2010). Assamese macaques are

165 characterized by female philopatry and male dispersal. At any time, all groups included several

166 adult males (7.4 (mean) $\pm 3.6(\mathrm{SD}))$ and adult females $(11.8$ (mean) $\pm 3.9(\mathrm{SD}))$, as well as a large

167 number of immatures. This study focused on adult females $(n=59)$, with females defined as

168 adult in the mating season of their first conception. For 25 of these females the mother and 
170 population when the project started in 2006 , so no information on their mother was available

171 and age was estimated based on morphology and behaviour.

172 This study was conducted completely non-invasively and adhered to the ASAB/ABS Guidelines

173 for the Use of Animals in Research. The Department of National Parks, Wildlife and Plant

174 Conservation (DNP) and the National Research Council of Thailand (NRCT) authorized data

175 collection and export of samples with a benefit sharing agreement (permit numbers:

176 0004.3/3618, 0002.3/2647, 0002/17, 0002/2424, 0002/470).

\section{Behavioural data collection}

178 We followed the study groups from dawn to dusk, from sleep tree to sleep tree. During 40

179 minutes continuous focal animal observations, we recorded frequencies and durations along

180 with actor and receiver of affiliative behaviours (grooming, body contact and approaches into

181 and departures from a $1.5 \mathrm{~m}$ radius around the focal individual). An effort was made to balance

182 focal animal protocols across individuals and time of day per study period (143 (mean) \pm 13 (SE)

183 hours/female, 8412 hours total).

184 Composite sociality index

185 To measure the strength of affiliative relationships among adult females, we used a modified

186 dyadic composite sociality index (CSI; Silk et al., 2006). In this study, the CSI is based on the

187 frequency $(F)$ and duration (D) of the following social behaviours: proximity within $1.5 \mathrm{~m}(\mathrm{P})$,

188 body contact $(\mathrm{B})$ and grooming $(\mathrm{G})$. It is calculated as the sum of the dyadic frequency and

189 duration of every behaviour, divided by the mean group frequency or duration of that

190 behaviour and then divided by the number of behaviours (=6): $C S I=$ 
$191 \frac{\frac{G F i j}{G F x y}+\frac{G D i j}{G D x y}+\frac{B F i j}{B F x y}+\frac{B D i j}{B D x y}+\frac{P F i j}{P F x y}+\frac{P D i j}{P D x y}}{6}$, with GFij = grooming frequency for dyad $\mathrm{ij}, \mathrm{GFxy}=$ mean

192 grooming frequency for all dyads in group $x$ and year $y$, etc. CSI values thus express the extent

193 to which a dyad's affiliation deviates from the average female dyad in a given group and period.

194 The CSI ranges from 0 to infinity, with an average of 1 and stronger than average relationships

195 for the respective group and period indicated by values higher than 1 . Time spent in proximity

196 was subtracted from the time spent in body contact and time spent in body contact was

197 subtracted from time spent grooming to not double the impact of nested interactions. All

198 behaviours were corrected for dyadic observation time (i.e. the sum of observation time for

199 each dyad member during which the other dyad member was adult and present as well). Before

200 calculating CSI values, we checked that mean frequencies of each behaviour exceeded 2, to

201 ensure that enough data was available to compute a meaningful CSI value for a given period.

202 All six behavioural measures included in the index were significantly positively correlated (row-

203 wise matrix correlations for all pair-wise combinations: average row-wise tau values ranging

204 from 0.34 to 0.85 across years and groups).

\section{Faecal sample collection}

206 Faecal samples for genetic analyses had been collected non-invasively since the start of the

207 project in 2006. About $5 \mathrm{~g}$ of material was scratched from the surface of excrements

208 immediately after defecation by an identified individual. We applied the two-step storage

209 procedure (Nsubuga et al., 2004): the faecal material was stored in a $50 \mathrm{~mL}$ falcon tube

210 (62.559.001, Sarstedt, Nümbrecht, North Rhine-Westphalia, Germany) containing 30ml of 97\%

211 ethanol and labelled with animal ID, time, date and collector. Samples were collected

212 opportunistically throughout the day. Twenty-four to 36 hours after collection, the ethanol was 
213 carefully poured off, and the remaining solid material was transferred to a new 50ml falcon

214 tube containing silica gel beads (112926- 00-2, Intereducation Supplies Co., Ltd., Bangkok,

215 Thailand). Samples were stored at room temperature in the dark until shipped to the German

216 Primate Center (DPZ) for further analysis. Multiple independent faecal samples have been

217 collected for each individual since 2006 and are stored at $-20^{\circ} \mathrm{C}$ until DNA extraction.

\section{DNA extraction \& genotyping}

219 DNA was extracted from 100-150mg of faeces at the Primate Genetics Laboratory (DPZ,

220 Goettingen), using the First-DNA all-tissue kit (D1002000, GEN-IAL GmbH, Troisdorf, North

221 Rhine Westphalia, Germany). We followed the manufacturer's protocol for DNA extraction

222 from faeces, using DNA LoBind Tubes (0030108051, 0030108078, Eppendorf AG, Hamburg,

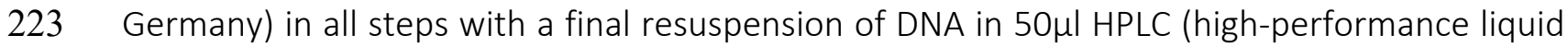

224 chromatography) water. We measured the DNA concentration of the extracts using NanoDrop

225 (Spectrophotometer ND-1000, PEQLAB Biotechnologie GmbH, Erlangen, Bavaria, Germany), and diluted them to a concentration of $100 \mathrm{ng} / \mu \mathrm{l}$ for further use in standard PCR.

227 Eighty-eight individuals of the same population had been genotyped previously at 15 autosomal

228 microsatellite loci (Table 1; Sukmak et al., 2014). We continued this effort for the remaining 48

229 individuals of the population that were adult before 2016, using the same procedures, and

230 included 2 additional microsatellite loci for all 136 individuals (D1s548 \& D7s2204; established

231 for crested macaques - Macaca nigra in Engelhardt, Muniz, Perwitasari-Farajallah, \& Widdig,

232 2017). We followed the two-step multiplex PCR approach (Arandjelovic et al., 2009): first, we 
$235(10 \mathrm{mM})$ per reaction for the singleplex reactions. We added BSA (bovine serum albumin,

$23620 \mathrm{mg} / \mathrm{ml})$ and $\mathrm{MgCl}_{2}(25 \mathrm{mM})$ to all reactions to enhance PCR performance and used SuperTaq

237 DNA polymerase (020503, Cambio Ltd, Cambridge, United Kingdom) combined with TaqStart

238 Antibody (639250, Takara Bio Europe, Saint-Germain-en-Laye, France) to prevent non-specific

239 amplification. Multiplex reaction conditions for all primer pairs were initial denaturation at 94

$240{ }^{\circ} \mathrm{C}$ for $9 \mathrm{~min}, 29$ cycles of denaturation at $94{ }^{\circ} \mathrm{C}$ for $20 \mathrm{~s}$, annealing at $50{ }^{\circ} \mathrm{C}$ for $30 \mathrm{~s}$, and

241 extension at $72{ }^{\circ} \mathrm{C}$ for $30 \mathrm{~s}$, then a final extension at $72{ }^{\circ} \mathrm{C}$ for 4 min. Singleplex reactions

242 followed the same conditions, but with an annealing temperature of $51.9^{\circ} \mathrm{C}$. For the singleplex

243 reactions, the forward primers were fluorescently labelled at the $5^{\prime}$ end (Table 1 ). After running

244 the singleplex products together with a non-template control on $1.5 \%$ agarose gels, we made

245 dilutions (pure product to 1:50 dilution) for every sample based on the brightness of the band.

246 We ran these dilutions on an ABI 3130xL sequencer (Applied Biosystems) and used the software

247 Geneious (version 11.0.4, www.geneious.com) to determine product sizes relative to the ROX

248 HD400 internal size standard.

249 To control for possible misidentification of individuals in the field, we genotyped all individuals

250 from two different samples; to control for mistakes in the lab, we genotyped every extraction

251 two times independently (multiple-tube approach; Navidi, Arnheim, \& Waterman, 1992;

252 Taberlet et al., 1996), leading to four genotypes per individual. An allele was accepted when it

253 appeared at least in three of those four genotypes, and at least once for every independent

254 extract. To protect against false homozygosity from allelic dropout, we accepted a locus as

255 homozygous only if the allele occurred independently at least seven times, according to

256 guidelines for attaining 99\% statistical confidence in genotyping (Taberlet et al., 1996). One

257 locus (D8s1106) was excluded as genotyping often failed, and a closer look at the sequence of 
the forward primer binding region showed that an insertion in the macaque DNA sequence (compared to human DNA for which the primer was developed) caused the primer to not bind properly. We checked the genotypes with Micro-Checker (version 2.2.3; Van Oosterhout,

261 Hutchinson, Wills, \& Shipley, 2004) and found no evidence for the occurrence of null alleles,

262 large allele drop-out or scoring error due to stutter. For 133 of the 136 individuals, genotypes

263 were generated for at least 8 of the 16 remaining loci (typed at 13.2 (mean) \pm 1.6 (SD) loci,

264 mean proportion of loci typed 81.66\%). The 3 individuals with <8 loci typed were excluded from

265 parentage analyses. We tested that all loci were in Hardy-Weinberg equilibrium using

266 PopGenReport (version 3.0.0; Adamack \& Gruber, 2014), and found that locus D1s548 departs

267 from Hardy-Weinberg equilibrium, which is attributable to the presence of close relatives in

268 the study group. Mean number of alleles per locus was 7.2, mean polymorphic information content (PIC) was 0.69 and mean expected heterozygosity was 0.74 , all calculated using Cervus

270 (version 3.0.0; Kalinowski, Taper, \& Marshall, 2007).

271 Apart from the 16 microsatellite loci, we also genotyped all individuals at the hypervariable

272 region I of the mitochondrial D-loop region. Mitochondrial DNA (mtDNA) is maternally 273 inherited, so candidate mothers for parentage analysis (see below) were restricted to females

274 with a matching mtDNA haplotype, which helped reduce misclassification rates (Kopps, Kang,

275 Sherwin, \& Palsboll, 2015). PCRs were performed using the primers $5^{\prime}$ -

276 AAATGAACCTGCCCTTGTAGT-3' and 5'-GAGGATAGAACCAGATGTCC-3' with initial denaturation

277 at $94{ }^{\circ} \mathrm{C}$ for $5 \mathrm{~min}, 40$ cycles of denaturation at $94{ }^{\circ} \mathrm{C}$ for $1 \mathrm{~min}$, annealing at $50{ }^{\circ} \mathrm{C}$ for $1 \mathrm{~min}$, 278 and extension at $72{ }^{\circ} \mathrm{C}$ for $1.5 \mathrm{~min}$, then a final extension at $72{ }^{\circ} \mathrm{C}$ for $5 \mathrm{~min}$. $\mathrm{PCR}$ products 279 together with a non-template control were checked on $1 \%$ agarose gels and then cleaned with 
bioRxiv preprint doi: https://doi.org/10.1101/714253; this version posted July 26, 2019. The copyright holder for this preprint (which was not certified by peer review) is the author/funder, who has granted bioRxiv a license to display the preprint in perpetuity. It is made available under aCC-BY-NC-ND 4.0 International license.

281 Cycle Sequencing Kit (Applied Biosystems). In total we found four mtDNA haplotypes: one was

282 represented only in two of the four observed groups, two others only in the other two observed

283 groups (that were originally one group) and one was only found in immigrant males.

284 Table 1: Information on the 16 microsatellite loci used in this study

\begin{tabular}{|c|c|c|c|c|c|c|c|c|}
\hline Locus & $\begin{array}{l}\text { Repeat } \\
\text { motif }\end{array}$ & Primer sequence $\left(5^{\prime}-3^{\prime}\right)$ & $\mathrm{N}_{\mathrm{A}}$ & Size range & $\mathrm{H}_{\mathrm{O}}$ & $\mathrm{H}_{\mathrm{E}}$ & HWE-p & Null F \\
\hline D1s1656 & tetra & $\begin{array}{l}\text { F: FAM-GTGTTGCTCAAGGGTCAACT } \\
\text { R: GAGAAATAGAATCACTAGGGAACC }\end{array}$ & 7 & $130-154$ & 0.833 & 0.796 & 0.584 & -0.0409 \\
\hline D1s1675 & tetra & $\begin{array}{l}\text { F: HEX-CTAGCCAAGGCAGGTCTGTA } \\
\text { R: GCCTAGACAATGGGAGAGGT }\end{array}$ & 2 & $207-215$ & 0.540 & 0.460 & 0.075 & -0.0964 \\
\hline D2s1326 & tetra & $\begin{array}{l}\text { F: FAM-AGACAGTCAAGAATAACTGCCC } \\
\text { R: AGGGAATTCTCTGAGCTAATAC }\end{array}$ & 10 & $191-241$ & 0.933 & 0.853 & 0.640 & -0.0187 \\
\hline D2s1363 & tetra & $\begin{array}{l}\text { F: FAM-TTCTGCTTTCTCTGACTGTATCA } \\
\text { R: ATTCTTTGTCTCGCCAGTTG }\end{array}$ & 11 & $179-223$ & 0.757 & 0.812 & 0.107 & 0.0578 \\
\hline D3s1766 & tetra & $\begin{array}{l}\text { F: FAM-ACCACATGAGCCAATTCTGT } \\
\text { R: ACCCAATTATGGTGTTGTTACC }\end{array}$ & 7 & $204-232$ & 0.740 & 0.718 & 0.458 & -0.005 \\
\hline D3s1768 & tetra & $\begin{array}{l}\text { F: FAM-GGTTGCTGCCAAAGATTAGA } \\
\text { R: CACTGTGATTTGCTGTTGGA }\end{array}$ & 10 & $184-228$ & 0.852 & 0.790 & 0.338 & -0.0333 \\
\hline D5s1457 & tetra & $\begin{array}{l}\text { F: FAM-TAGGTTCTGGGCATGTCTGT } \\
\text { R: TGCTTGGCACACTTCAGG }\end{array}$ & 5 & $122-138$ & 0.629 & 0.699 & 0.157 & 0.0696 \\
\hline D6s1056 & tetra & $\begin{array}{l}\text { F: TAMRA-ACAAGAACAGCATGGGGTAA } \\
\text { R: CCTGGATCATGAATTGCTAT }\end{array}$ & 5 & $224-240$ & 0.766 & 0.695 & 0.064 & -0.0272 \\
\hline D9s910 & tri & $\begin{array}{l}\text { F: TAMRA-AAGTCAGTTAGCTGAAGGTTGC } \\
\text { R: TATATGAAGTGCTTAGAAAAAGTGC }\end{array}$ & 7 & $99-117$ & 0.732 & 0.691 & 0.631 & -0.0547 \\
\hline D9s934 & tetra & $\begin{array}{l}\text { F: HEX-TTTCCTAGTAGCTCAAGTAAAGAGG } \\
\text { R: AGACTTGGACTGAATTACACTGC }\end{array}$ & 4 & $186-198$ & 0.722 & 0.632 & 0.225 & -0.0884 \\
\hline D10s676 & tetra & $\begin{array}{l}\text { F: HEX-GAGAACAGACCCCCAAATCT } \\
\text { R: ATTTCAGTTTTACTATGTGCATGC }\end{array}$ & 12 & $192-244$ & 0.906 & 0.888 & 0.163 & -0.0073 \\
\hline D14s306 & tetra & $\begin{array}{l}\text { F: TAMRA-AAAGCTACATCCAAATTAGGTAGG } \\
\text { R: TGACAAAGAAACTAAAATGTCCC }\end{array}$ & 6 & $166-186$ & 0.740 & 0.667 & 0.706 & -0.0397 \\
\hline D17s804 & tetra & $\begin{array}{l}\text { F: HEX-GCCTGTGCTGCTGATAACC } \\
\text { R: CACTGTGATGAGATGTCATTCC }\end{array}$ & 5 & $150-168$ & 0.618 & 0.602 & 0.059 & 0.0065 \\
\hline D18s536 & tetra & $\begin{array}{l}\text { F: TAMRA-ATTATCACTGGTGTTAGTCCTCTG } \\
\text { R: CACAGTTGTGTGAGCCAGTC }\end{array}$ & 8 & $152-180$ & 0.823 & 0.788 & 0.836 & -0.024 \\
\hline D1s548 & tetra & $\begin{array}{l}\text { F: FAM-GAACTCATTGGCAAAAGGAA } \\
\text { R: GCCTCTTTGTTGCAGTGATT }\end{array}$ & 7 & $190-214$ & 1000 & 0.807 & 0.000 & -0.1113 \\
\hline D7s2204 & tetra & $\begin{array}{l}\text { F: TAMRA-TCATGACAAAACAGAAATTAAGTG } \\
\text { R: AGTAAATGGAATTGCTTGTTACC }\end{array}$ & 9 & $233-265$ & 0.961 & 0.824 & 0.725 & -0.0596 \\
\hline
\end{tabular}

286 Locus name, repeat motif, forward (F) and reverse (R) primer sequences with fluorescent label, number of

287 alleles $\left(\mathrm{N}_{\mathrm{A}}\right)$, observed heterozygosity $\left(\mathrm{H}_{\mathrm{O}}\right)$ \& expected heterozygosity $\left(\mathrm{H}_{\mathrm{E}}\right)$ using PopGenReport, $p$-value of the

288 Hardy-Weinberg equilibrium test (HWE-p) using PopGenReport (significant deviation $=p<(0.05 / 16)=0.003$,

289 marked in bold) and estimation of null allele frequencies (Null F) using Brookfield1 method in MicroChecker 


\section{Parentage assignment}

292 For every individual a conservative set of candidate parents was determined. All males that

293 were at least five years old at the time of birth of the individual were included as potential

294 fathers, all females that had the same mtDNA haplotype as the individual and were at least five

295 years old at the time of birth of the individual were included as potential mothers. From those

296 candidate parents, we assigned parentage using both the pairwise likelihood-basis paternity

297 analysis of Cervus (version 3.0.0; Kalinowski et al., 2007) and the full-pedigree likelihood

298 method of Colony (version 11.3.0; Jones \& Wang, 2010). Cervus assigns a parent by calculating

299 the difference in log-likelihood ratios (LOD score, the likelihood of parentage of a particular

300 parent compared to the likelihood of parentage of an arbitrary parent; Kalinowski et al., 2007).

301 Colony on the other hand considers likelihoods over the full pedigree, comparing different

302 clusterings of individuals, where individuals in a cluster are related via sibship or shared

303 parentage. Cervus assigned more parents than did Colony, but with the exception of one sire,

304 both Cervus and Colony assigned the same parents to individuals, confirming the reliability of

305 our parentage assignments. We therefore included all parents assigned at a strict (95\%

306 likelihood) level by Cervus in the analysis. Relatedness values ( $r$ ) were also calculated for every

307 dyad, by using the R package Related (version 1.0; Pew, Muir, Wang, \& Frasier, 2015) and the

308 triadic likelihood estimator (trioML; Wang, 2007).

310 Based on the parentage analyses, dyads were classified as mother-daughters, maternal half-

311 sisters, paternal half-sisters and non-kin. Individuals who belonged to more than one kin

312 category, such as full siblings, were excluded from the analysis. Non-kin dyads were defined as

313 dyads for whom both parents of each dyad member were known and not shared, and had a 
314 relatedness value lower than 0.125 . Out of the 513 female-female dyads for which we had

315 behavioural data (i.e. who were adults living in the same group at some point during the 6 years

316 of observational data available), we were able to assign a total of 161 to one of those kin classes

317 (Table 2). The remaining dyads either belonged to more than one kin category (3 full sibling

318 dyads, 2 mother-offspring dyads who were also paternal half-sisters), shared no parents but

319 did not fit the threshold of $r<0.125$ for non-kin (130 dyad) or we lacked parentage information

320 to reliably assign them to a kin class (217 dyads).

Table 2: Number of adult females assigned to each kin category and average relatedness (TrioML after Wang, 2007) of all dyads in that kin class

\begin{tabular}{|c|c|c|c|c|}
\hline Kin class & Non-kin & $\begin{array}{c}\text { Paternal } \\
\text { half-sisters }\end{array}$ & $\begin{array}{c}\text { Maternal } \\
\text { half-sisters }\end{array}$ & $\begin{array}{c}\text { Mother- } \\
\text { daughters }\end{array}$ \\
\hline Nr. of dyads & 94 & 12 & 21 & 34 \\
\hline $\begin{array}{c}\text { Average } \\
\text { relatedness }\end{array}$ & 0.033 & 0.285 & 0.244 & 0.472 \\
\hline
\end{tabular}

323

\section{Statistical analyses}

326 All analyses were run in R (version 3.4.4; R Development Core Team, 2018), using the Rstudio

327 interface (version 1.0.153; RStudio Team, 2016). Since our data set was longitudinal, with

328 repeated measures across several years and groups we ran linear mixed models, to allow to

329 control for non-independence of the data, using the R package Ime4 (Bates, Mächler, Bolker,

330 \& Walker, 2015). For all models, we checked the assumption of normally distributed and

331 homogeneous residuals by visually inspecting a qqplot and scatterplot of the residuals plotted

332 against the fitted values. None of the models showed obvious deviations from these

333 assumptions. Model stability was tested by excluding data points one by one from the data and 
334 comparing the model estimates for the subsets to the estimates for the full data set. No

335 influential cases were found in any of our models. We checked that the predictors of interest

336 were not collinear by calculating Variance Inflation Factors (VIF) using the function vif of the R

337 package car (Fox \& Weisberg, 2011) applied to a standard linear model excluding the random

338 effects. VIFs were close to one for all models, indicating collinearity not to be an issue.

339 Covariates were z-transformed to a mean of 0 and standard deviation of 1 to allow for

340 comparison of effect sizes. All statistical analyses were performed on a dyadic level. To make

341 sure that assigning a member of the dyad to ID1 or ID2 had no influence, the models were

342 iterated 10,000 times, with random assignment of dyad members to either ID1 or ID2. For all

343 models, we performed a full-null model comparison, with the null model containing only the

344 control predictors, to test whether inclusion of predictors improved model fit. P-values for

345 significance of each level of the categorical predictors were obtained by using the function glht

346 or the R package multicomp, that corrects for multiple comparisons (Hothorn, Bretz, \& 347 Westfall, 2008).

349 Models 1\&2: social bond strength and time spent grooming in the different kin

350 classes

351 To analyse whether kin class influences dyadic social bond strength, we ran a Linear Mixed

352 Model with kin class as the predictor, and the square root of the dyadic CSI value as the 353 response. Group, year, dyad, ID1 and ID2 were included as random effects, and kin class within 354 group and within year were included as random slopes. We ran the model once with non-kin 355 as the reference level, to test whether the three related kin classes (maternal and paternal half356 sisters and mother-daughters) differed from non-kin in their social bond strength, and then 
releveled the variable kin class to paternal half-sisters, to test for differences between paternal

358 half-sisters and close maternal kin. To check the robustness of the results we ran the same model with the square root of time spent grooming - an unambiguously friendly and directed

360 behaviour - as the response. For both these models all assigned dyads were included: 94 non-

361 kin dyads (171 observations), 12 paternal half-sisters (21 observations), 21 maternal half-sisters

362 (54 observations) and 34 mother-daughter dyads (73 observations).

363

364 Model 3: the effect of close maternal kin availability on paternal kin biases

365 To assess whether availability of maternal kin influences bond strength with paternal half-

366 sisters compared to non-kin, we ran a Linear Mixed Model with the sum of the number of close

367 maternal kin (i.e. adult and alive mother, daughters and maternal half-sisters) for both partners

368 of each dyad and kin class as predictor variables, and the square root of the dyadic CSI value as

369 the response. Dyad, ID1 and ID2 were included as random effects. We restricted this analysis

370 to two of the four observed groups on which we have data since 2006, as we have sampled

371 more mothers of the currently adult females in those groups and the proportion of assigned

372 dyads is higher (49\%). Individuals had on average 1.97 close maternal kin available (ranging

373 from 0 to 5), the sum of close maternal kin available to both partners of a dyad was on average

3743.94 (ranging from 1 to 8). For this model we had 81 non-kin dyads (146 observations) and 9

375 paternal half-sisters (16 observations). 
378 To test whether the bias towards paternal kin was more pronounced for paternal half-sisters

379 closer in age, we ran a Linear Mixed Model with the square root of the age difference, kin class

380 and the interaction between age difference and kin class as predictor variables, and the square

381 root of the dyadic CSI value as the response. Group, year, dyad, ID1 and ID2 were included as

382 random effects, but no random slopes were included in this model, as there were not enough

383 levels for kin class or values for age difference with at least two dyads per group or year. Age

384 difference ranged from 0 to 11 years. We also ran the same model with a binary predictor same

385 age cohort or not (i.e. born in the same year or not) instead of age difference (21 dyads born

386 in the same cohort, 36 observations; 85 dyads born in a different cohort, 156 observations).

387 For both these models we used a subset of the data including only non-kin (94 dyads, 171

388 observations) and paternal half-sisters (12 dyads, 21 observations).

390 RESULTS

391 Social bond strength and time spent grooming in the different kin classes

392 (Models 1\&2)

393 Overall, the full model with social bond strength as the response and including kin class as

394 predictor was highly significant compared to the null model (likelihood ratio test: $\chi^{2}=14.59$

$395[12.03,16.25], d f=3, p=0.002[0.001,0.007]$, mean [minimum, maximum] over 10,000 tests),

396 meaning that the multi-level variable kin class had a significant effect on the strength of dyadic

397 social bonds (reference level: non-kin; marginal $R^{2}=0.14[0.12,0.16]$, mean [minimum,

398 maximum] over 10,000 tests). More specifically, we found significantly stronger bonds between

399 dyads of all related kin classes (paternal half-sisters, maternal half-sisters and mother-

400 daughters) compared to non-kin dyads (Figure 1 \& Table 3). After releveling the variable kin 
401 class to paternal half-sisters, we did not find significant differences in social bond strength

402 between paternal half-sisters and maternal kin. The full model with time spent grooming as the

403 response and including kin class as predictor was highly significant compared to the null model

404 as well (likelihood ratio test: $\chi^{2}=12.71[11.50,14.87]$, $d f=3, p=0.005[0.002,0.009]$, mean

405 [minimum, maximum] over 10,000 tests), meaning that the multi-level variable kin class also

406 had a significant effect on the time spent grooming (reference level: non-kin; marginal $\mathrm{R}^{2}=0.18$

407 [0.16, 0.20], mean [minimum, maximum] over 10,000 tests). (Figure 2 \& Table 4).

408

409 Table 3: Effect of kin class on dyadic social bond strength

\begin{tabular}{|c|c|c|c|c|}
\hline term & Estimate & Standard Error (SE) & $t$ score & $p$ value \\
\hline intercept & $0.825[0.797,0.860]$ & $0.052[0.047,0.063]$ & - & - \\
\hline $\begin{array}{c}\text { paternal } \\
\text { half-sisters }\end{array}$ & $0.311[0.212,0.373]$ & $0.117[0.109,0.120]$ & $2.665[1.832,3.229]$ & $0.03[0.03,0.04]$ \\
\hline $\begin{array}{c}\text { maternal } \\
\text { half-sisters }\end{array}$ & $0.232[0.157,0.306]$ & $0.082[0.078,0.091]$ & $2.813[1.951,3.648]$ & $0.01[0.01,0.01]$ \\
\hline $\begin{array}{c}\text { mother- } \\
\text { daughter }\end{array}$ & $0.502[0.461,0.541]$ & $0.125[0.112,0.138]$ & $3.992[3.457,4.588]$ & $0.0001[0.0001,0.0005]$ \\
\hline
\end{tabular}

410

411 model estimates (mean [minimum, maximum]) for the 10,000 iterations of the model with non-kin as reference level

412 linear mixed model: sqrt(CSI) kin class + (1+kin class | group) + (1+kin class | |year) + (1|dyad) + (1|focal_animal) +

413 (1|action_partner)

414 t score \& $p$ value for intercept not shown because of limited interpretation

415

416 


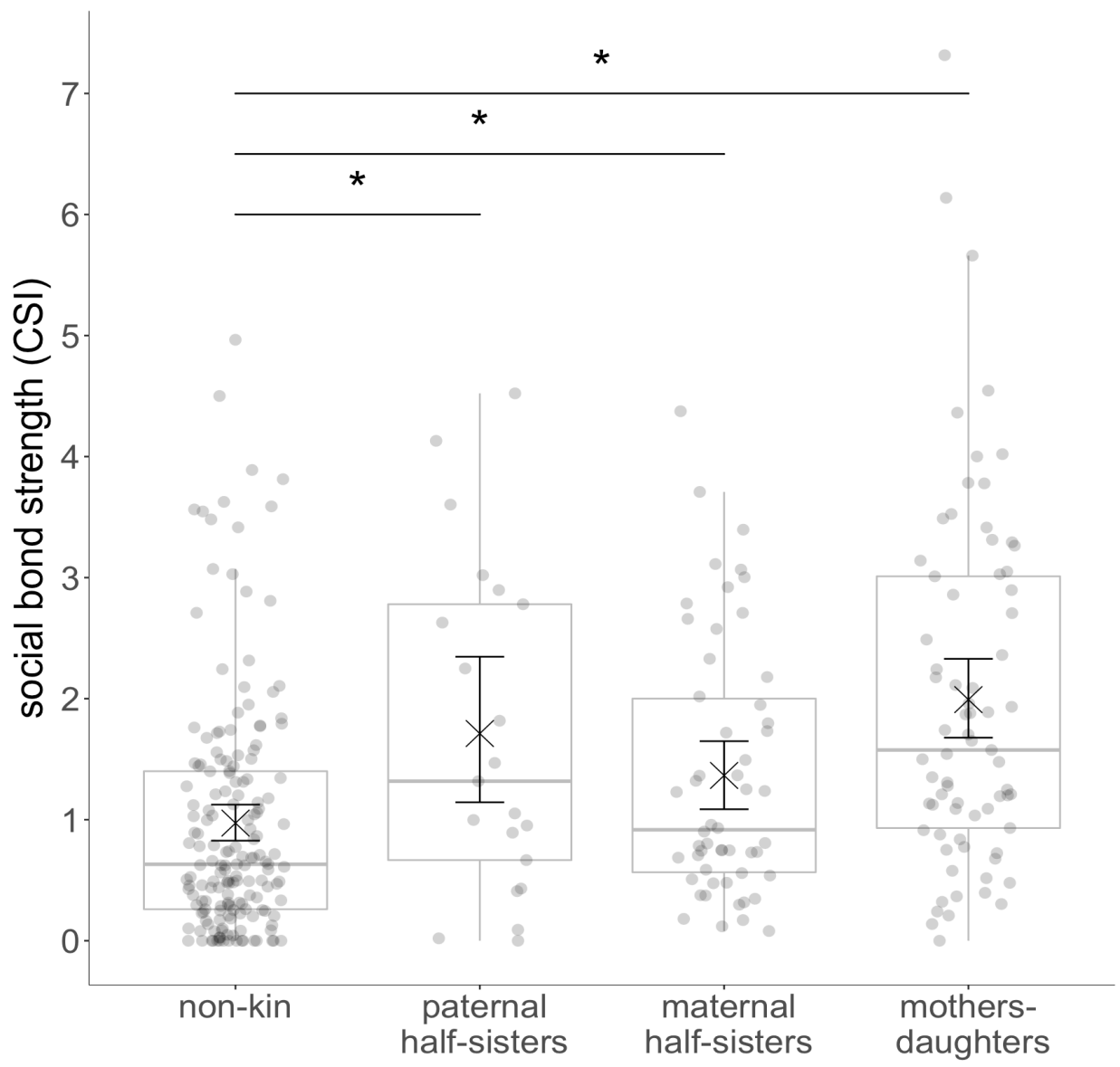

418

Figure 1: Effect of kin class on dyadic social bond strength. Points depict dyads of adult females in each kin class. Boxplots depict the median, the lower and upper quartiles (25\% and $75 \%)$, and the range excluding outliers. (x) depict the mean, and the whiskers around it depict the $95 \%$ confidence intervals.

Table 4: Effect of kin class on time spent grooming in a dyad

\begin{tabular}{|c|c|c|c|c|}
\hline term & estimate & Standard Error (SE) & t score & $p$ value \\
\hline $\begin{array}{c}\text { intercept } \\
\text { paternal } \\
\text { half-sisters }\end{array}$ & $-1.628[-1.706,-1.567]$ & $0.102[0.092,0.122]$ & - & - \\
\hline $\begin{array}{c}\text { maternal } \\
\text { half-sisters }\end{array}$ & $0.370[0.295,0.500]$ & $0.124[0.122,0.184$ & $2.983[2.132,3.389]$ & $0.009[0.008,0.01]$ \\
\hline $\begin{array}{c}\text { mother- } \\
\text { daughter }\end{array}$ & $0.931[0.894,1.000]$ & $0.260[0.259,0.285]$ & $3.576[3.230,4.051]$ & $0.001[0.001,0.002]$ \\
\hline
\end{tabular}

425 model estimates (mean [minimum, maximum]) for the 10,000 iterations of the model with non-kin as reference level

426 linear mixed model: sqrt(grooming duration) $\sim$ kin class $+(1+$ kin class || group $)+(1+$ kin class $\mid$ |year $)+(1 \mid$ dyad $)+$

427 (1|focal_animal) + (1|action_partner)

428 t score \& $p$ value for intercept not shown because of limited interpretation 


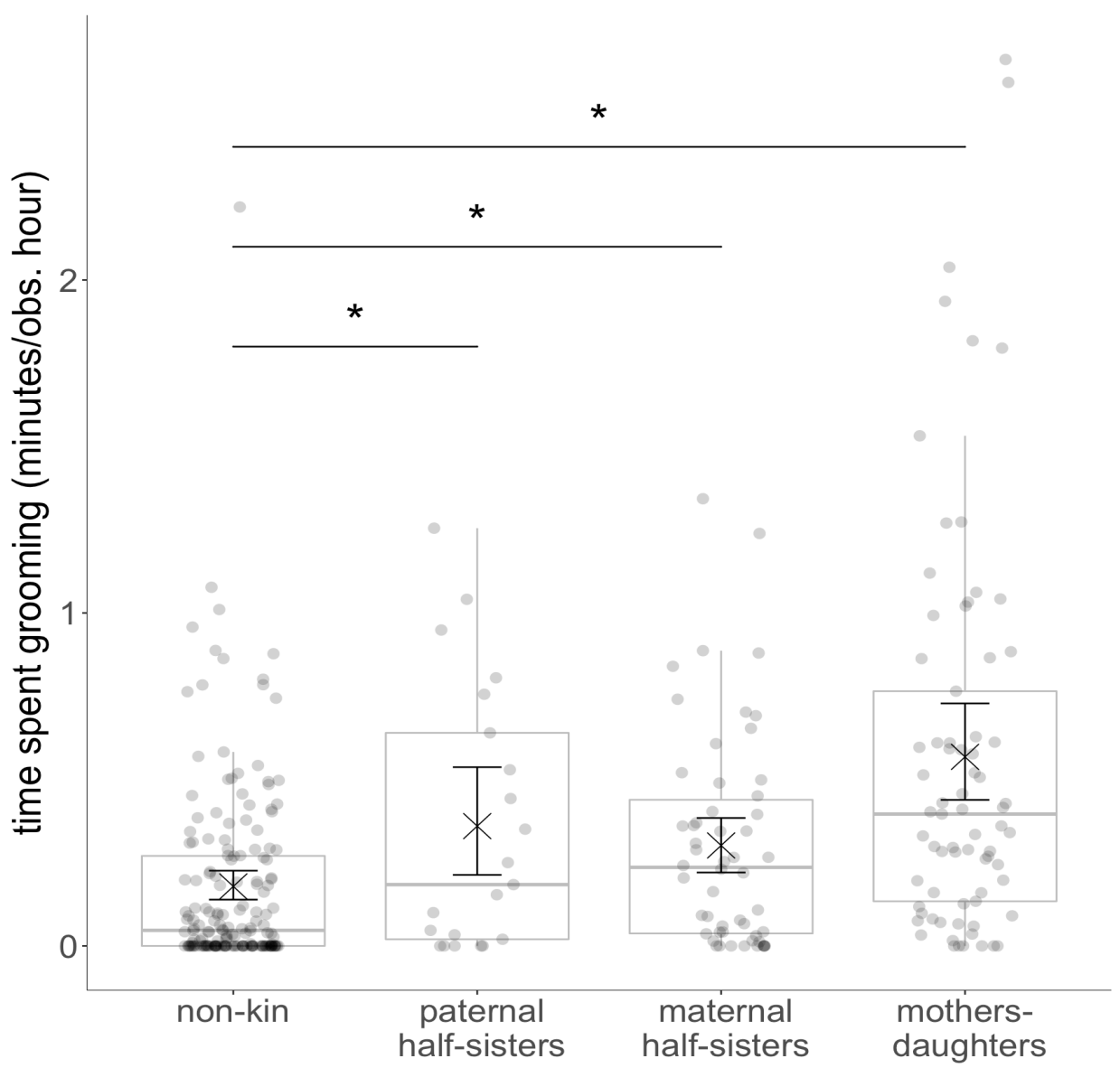

Figure 2: Effect of kin class on time spent grooming. Points depict dyads of adult females in each kin class. Boxplots depict the median, the lower and upper quartiles (25\% and $75 \%$ ), and the range excluding outliers. (x) depict the mean, and the whiskers around it depict the $95 \%$ confidence intervals.

437 The full model with kin class and sum of close maternal kin available (mothers, adult daughters

438 and adult maternal half-sisters) as predictors of bond strength was a significantly better fit to

439 the data than the null model (likelihood ratio test: $\chi^{2}=8.8[4.5,11.3], d f=2, p=0.01[0.003$,

440 0.1], mean [minimum, maximum] over 10,000 tests). Because the interaction between kin class

441 and sum of close maternal kin available was not significant, the interaction term was excluded

442 in the final model. Together, kin class and sum of close maternal kin available explained some

443 of the variation in the data (marginal $R^{2}=0.05[0.03,0.07]$, mean [minimum, maximum] over 
44410,000 tests). As in the previous models, paternal half-sisters formed significantly stronger

445 bonds than the non-kin dyads. The sum of close maternal kin available had no significant effect

446 on social bond strength, but especially for the paternal half-sisters the sample size might be

447 too small to detect such an effect (see Figure 3 \& Table 5). Moreover, this finding should be

448 interpreted with caution, as there were most likely more maternal kin available in the dyads

449 we could not reliably assign to a kin class.

450

451

Table 5: Effect of maternal kin availability on dyadic social bond strength of paternal half-sisters and non-

452

kin

\begin{tabular}{|c|c|c|c|c|}
\hline Term & estimate & Standard Error (SE) & t score & p value \\
\hline Intercept & $0.839[0.822,0.862]$ & $0.045[0.044,0.063]$ & - & - \\
\hline $\begin{array}{c}\text { paternal } \\
\text { half-sisters }\end{array}$ & $0.360[0.265,0.424]$ & $0.139[0.131,0.141]$ & $2.599[1.928,3.099]$ & $0.03[0.03,0.03]$ \\
\hline $\begin{array}{c}\text { sum of close } \\
\text { maternal kin }\end{array}$ & $0.071[0.003,0.104]$ & $0.042[0.042,0.048]$ & $1.679[0.067,2.375]$ & $0.22[0.22,0.22]$ \\
\hline
\end{tabular}

model estimates (mean [minimum, maximum]) for the 10,000 iterations of the model with non-kin as reference level linear mixed model: sqrt(CSI) kin class + z.sum of close maternal kin + (1+z.sum close maternal kin| |group) $+(1+z$.sum close maternal kin ||year $)+(1 \mid$ dyad $)+(1 \mid$ focal_animal $)+(1 \mid$ action_partner $)$

t score \& p value for intercept not shown because of limited interpretation 


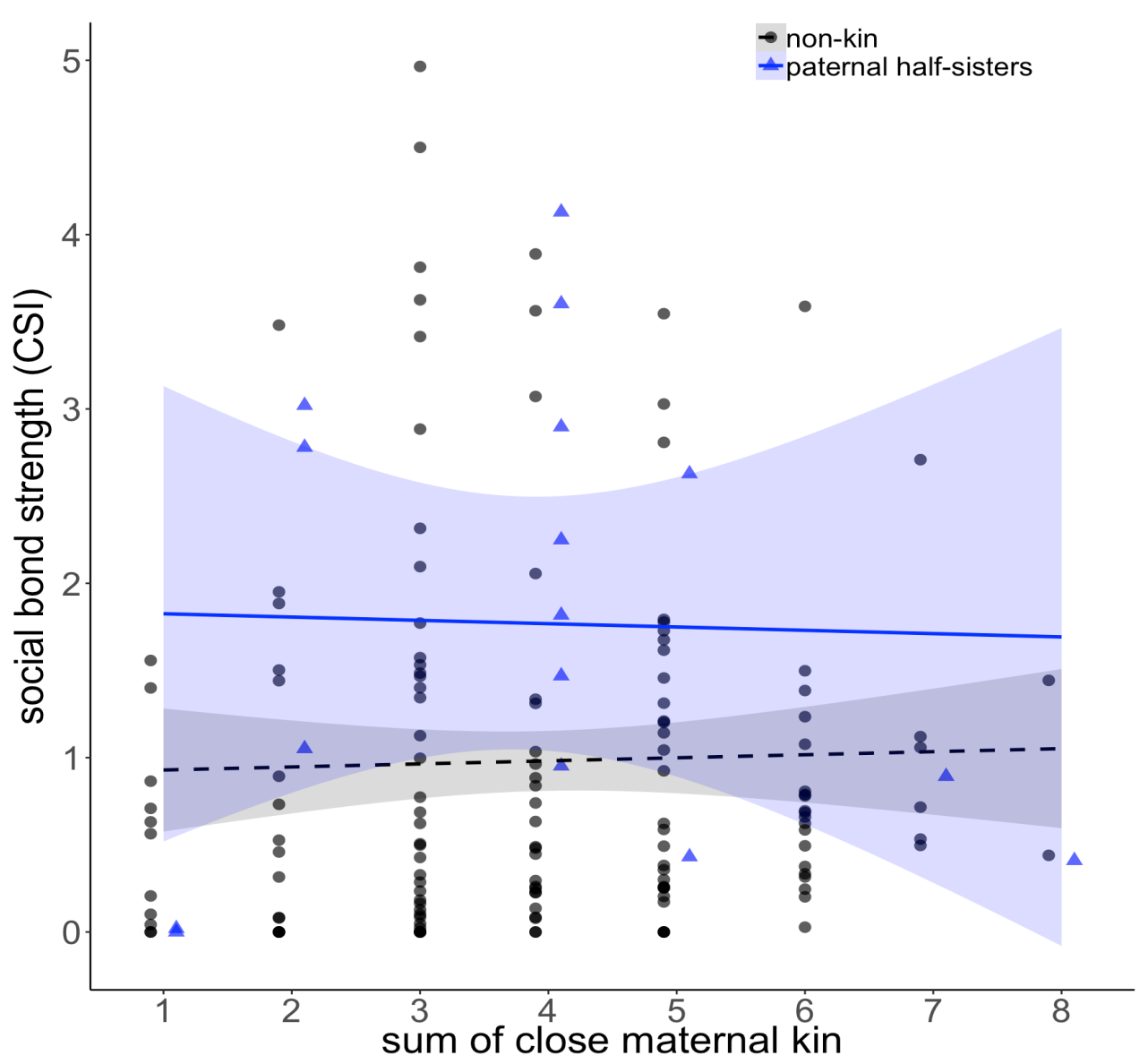

461 Figure 3: Effect of maternal kin availability on dyadic social bond strength of paternal half-sisters and non-kin. Black dots depict 462 non-kin dyads, with the dotted black line depicting the least squares linear regression line with the $95 \%$ confidence interval around it. Blue triangles depict paternal half-sister dyads with the solid blue line depicting the least squares linear regression line with the 95\% confidence interval around it.

467 The full model with kin class, age difference, and their interaction as predictors of bond

468 strength fitted the data significantly better than the null model (likelihood ratio test: $\chi^{2}=6.5$

$469[4.4,8.8], d f=2, p=0.04[0.01,0.11]$, mean [minimum, maximum] over 10,000 tests). The

470 interaction between kin class and age difference was not significant, so interaction term was

471 removed from the final model. Together, kin class and age difference explained some of the

472 variation in social bond strength (marginal $R^{2}=0.03[0.03,0.05]$, mean [minimum, maximum]

473 over 10,000 tests). As in the previous model with the full dataset, bonds between paternal half- 
474 sisters were significantly stronger than bonds between non-kin dyads. Age difference had no

475 significant effect on social bond strength (Figure 4 \& Table 6).

476 When running the model with a binary variable coding for whether partners were born the

477 same year or not, the full model was a better fit to the data than the null model too [likelihood

478 ratio test: $\chi^{2}=8.3[4.3,12.1], \mathrm{df}=2, \mathrm{p}=0.02[0.002,0.12]$, mean [minimum, maximum] over 10,000 tests). Together kin class and cohort explained some of the variation in social bond

Table 6: Effect of age difference on dyadic social bond strength of paternal half-sisters and non-kin

\begin{tabular}{|c|c|c|c|c|}
\hline Term & estimate & Standard Error (SE) & t score & p value \\
\hline Intercept & $0.848[0.833,0.866]$ & $0.041[0.039,0.057]$ & - & - \\
\hline $\begin{array}{c}\text { paternal } \\
\text { half-sisters }\end{array}$ & $0.310[0.209,0.359]$ & $0.119[0.113,0.121]$ & $2.614[1.781,3.128]$ & $0.02[0.02,0.02]$ \\
\hline age difference & $-0.046[-0.070,-0.029]$ & $0.037[0.037,0.041]$ & $-1.225[-1.805,-0.725]$ & $0.52[0.52,0.52]$ \\
\hline
\end{tabular}




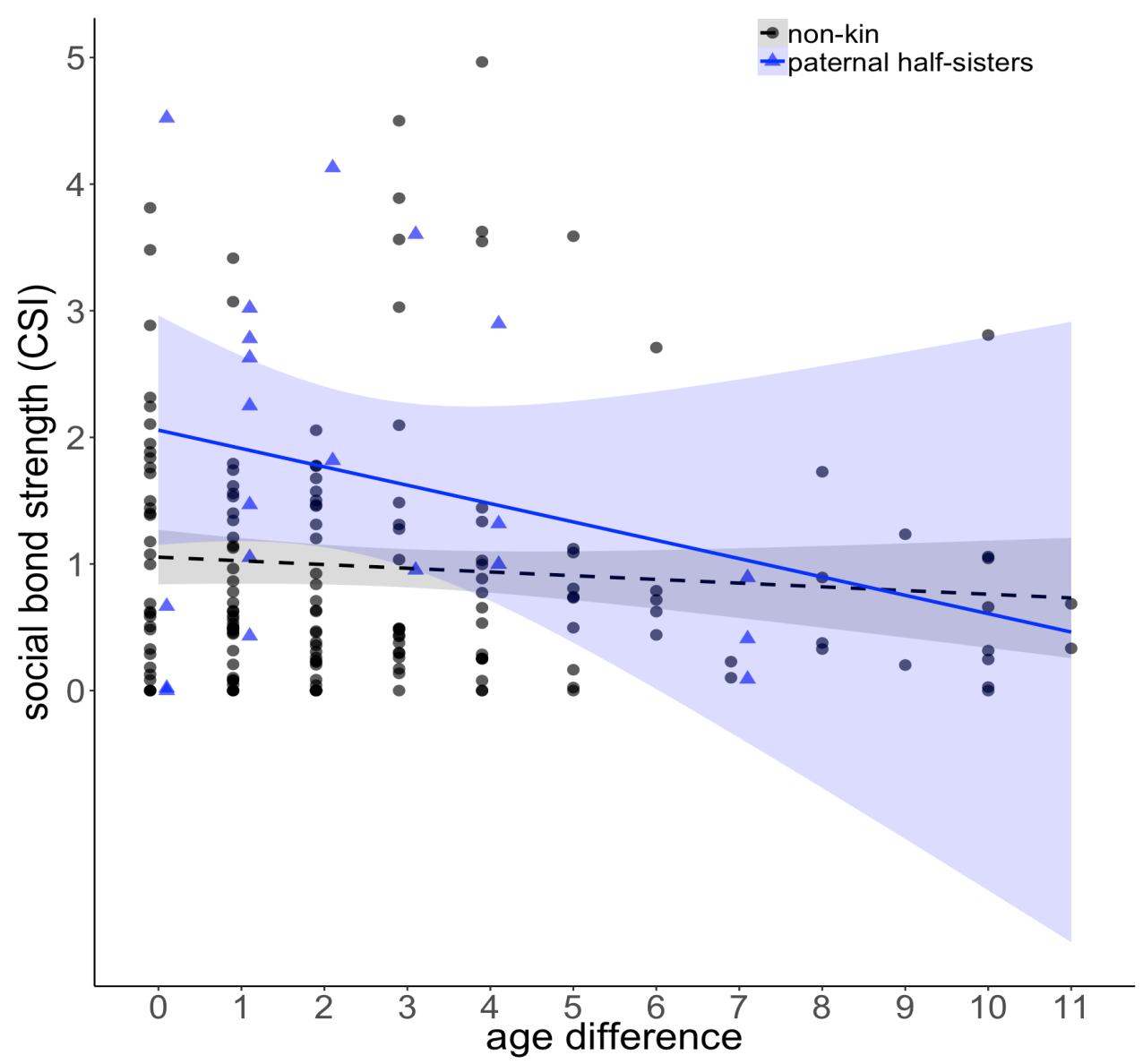

Figure 4: Effect of age difference on dyadic social bond strength of paternal half-sisters and non-kin. Black dots depict nonkin dyads, with the dotted black line depicting the least squares linear regression line with the $95 \%$ confidence interval around it. Blue triangles depict paternal half-sister dyads with the solid blue line depicting the least squares linear regression line with the 95\% confidence interval around it.

Table 7: Effect of age cohort on dyadic social bond strength of paternal half-sisters and non-kin

\begin{tabular}{|c|c|c|c|c|}
\hline Term & estimate & Standard Error (SE) & t score & p value \\
\hline Intercept & $0.926[0.899,0.969]$ & $0.088[0.086,0.094]$ & - & - \\
\hline $\begin{array}{c}\text { paternal } \\
\text { half-sisters }\end{array}$ & $0.315[0.247,0.370]$ & $0.119[0.113,0.122]$ & $2.660[2.118,3.209]$ & $0.018[0.016,0.020]$ \\
\hline age cohort & $-0.095[-0.154,-0.064]$ & $0.096[0.094,0.100]$ & $-0.998[-1.613,-0.668]$ & $0.611[0.611,0.611]$ \\
\hline
\end{tabular}




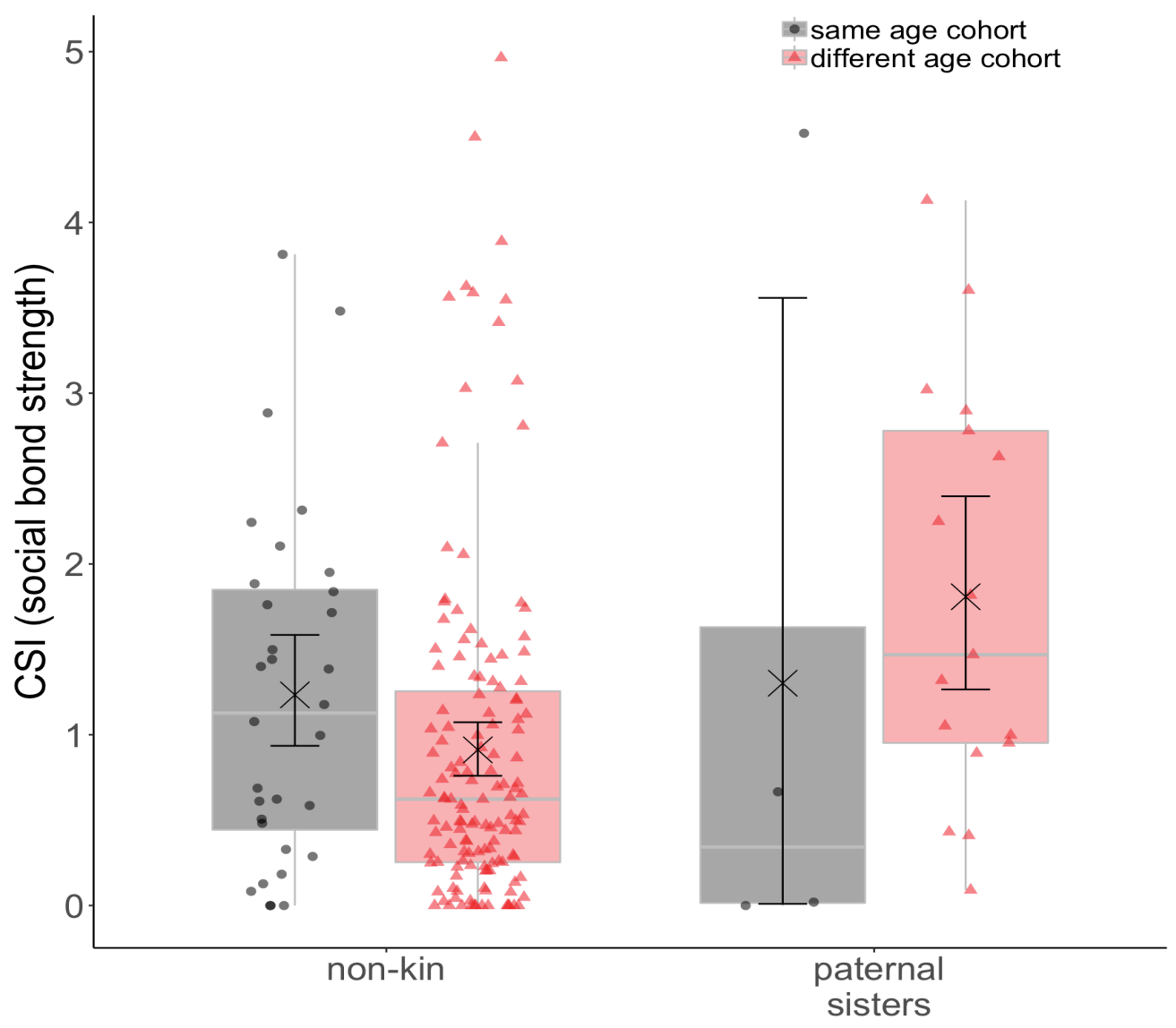

505 Figure 5: Effect of age cohort on dyadic social bond strength of paternal half-sisters and non-kin. Black dots and boxplots 506 depict dyads born in the same age cohort, red triangles and boxplots depicts dyads born in different age cohorts. Boxplots 507 depict the median, the lower and upper quartiles (25\% and $75 \%$ ), and the range excluding outliers. (x) depict the mean, and 508 the whiskers around it depict the $95 \%$ confidence intervals.

509 Kin effects in group fission

510 Another source of evidence for the importance of maternal kinship in our species comes from

511 a group fission that occurred in one of our study groups in 2012 and led to a permanent

512 fission into two subgroups. During this event, two entire matrilines split off from the original

513 group, leaving no maternally related females behind and taking no other female with them. 


\section{DISCUSSION}

517 Kin biases are expected to develop if kin are available and reliably recognisable. In most

518 mammal species, maternal kin meet both criteria, and maternal relatedness has emerged as

519 one of the most important factors structuring mammal social organization and behaviour (Silk,

$5202009 ;$ J. E. Smith, 2014). Especially in stable social groups with female philopatry and overlap

521 of generations, strong mother-offspring bonds lead to the clustering of females into matrilines,

522 with maternal kin being closely associated and selectively directing affiliation towards each

523 other (Archie et al., 2006; Berman, 2015; J. E. Smith et al., 2010). As expected, we found that

524 maternal kinship impacted the sociality of female Assamese macaques. Maternal half-sisters

and mother-daughter dyads both formed stronger social bonds and spent more time grooming

526 than non-kin. The importance of maternal kinship was also reflected in the group fission we

observed, which happened fully along matrilines. This is in line with several studies in other

mammal species that find that both temporal fission in species with fission-fusion dynamics as

well as permanent group splits are predicted by genetic relationships, and especially maternal

relatedness (Archie et al., 2006; Carter, Seddon, Frère, Carter, \& Goldizen, 2013; Van Horn,

531 Buchan, Altmann, \& Alberts, 2007).

532

533 In contrast to maternal kin, paternal kin availability and recognition are less well understood,

534 and depend on species-specific factors such as dispersal and mating regime (Strier, 2004). Since

535 most mammal females mate with multiple partners during their fertile period, paternity is 
looked into how paternal relatedness affects sociality (Table 8), making it hard to draw

540 conclusions on which factors affect the development of biases towards paternal kin.

541 With this study, we addressed some of the gaps in what we know so far on paternal kin biases.

542 Assamese macaques have a relatively low male reproductive skew (29\% alpha male paternity:

543 Sukmak et al., 2014), and a relatively long alpha male tenure (Ostner et al., 2013), which

544 allowed us to test whether an affiliation bias towards paternal kin can develop in a species

545 where several individuals are expected to have paternal half-siblings available, but where those

546 paternal half-sisters usually belong to different age cohorts. Out of the 59 observed adult

547 females, 18 females had at least one paternal half-sister in the group for at least one of the

548 years of our study. Only 2 of the 12 (12.5\%) paternal half-sister dyads were born in the same

549 year (average age difference $2.7 a)$. Two of the $42(4.8 \%)$ dyads born in the same year were paternal half-sisters, compared to 10 of 471 dyads (2.1\%) born in different years.

552 We found that female Assamese macaques bias their affiliation towards paternal kin,

553 independent of age similarity. Paternal half-sisters formed stronger bonds and spent more time

554 grooming than did non-kin, but as expected we found no evidence for an effect of age proximity

555 on social bond strength. It seems that familiarity through age proximity is not a prerequisite for

556 paternal kin biases to develop, and that individuals might recognize their paternal kin through

557 other mechanisms. In fact, based on the limited data so far, the importance of familiarity via

558 age proximity is generally questionable (Langergraber, 2012; Widdig, 2013). If individuals

559 discriminate paternal kin solely based on growing up together, one would expect a preference

560 for all individuals (also non-kin) born in the same age cohort, the underlying assumption being

561 that most of those individuals are paternal kin (Altmann, 1979). Paternity is, however, rarely 
monopolized by one male, and in species in which the alpha male does sire a large proportion

563 of the offspring, he also usually has a relatively long tenure (Widdig, 2013; Table 8). Even in

564 species in which paternal kin biases are more pronounced among age mates, only a small

565 proportion of same-aged individuals are actually paternal kin (Table 8). So, although there is an

566 effect of age proximity in these species, the question is whether this attraction to same-aged

567 individuals really reflects a bias towards paternal kin. It is also important to note that paternal

568 kin biases are more pronounced, but not limited to age mates in all these species (Lynch et al.,

569 2017; K. Smith et al., 2003; Widdig et al., 2001), suggesting that individuals do not rely on age

570 proximity alone to discriminate paternal kin from non-kin. Moreover, similar to our finding,

571 other species show paternal kin biases in affiliation, but no effect of age similarity (Charpentier

572 et al., 2007; Cords et al., 2018). Age proximity thus might serve as a first, rather rough proxy

573 for paternal relatedness in some species, and individuals likely make use of other cues as well

574 to recognize their paternal kin.

575

576 An alternative, and so far rather understudied way through which paternal kin could recognize

577 each other is through mother- and/or father-mediated familiarity (Widdig, 2007). In Assamese

578 macaques, for example, males and females form strong, stable bonds that can last for several

579 years (Haunhorst, Schülke, \& Ostner, 2016). A male associated with a female during the mating

580 season is her main mating partner, and thus the most likely sire of her offspring (Ostner et al.,

581 2013). In other primate species too, males and females form associations that persist after the

582 female gave birth (Baniel, Cowlishaw, \& Huchard, 2016; Huchard et al., 2010; Lemasson,

583 Palombit, \& Jubin, 2008; Moscovice et al., 2010; Nguyen, Van Horn, Alberts, \& Altmann, 2009;

584 Van Schaik \& Kappeler, 1997), which might allow infants to get indirectly familiarized to their 
father early on in life. Infants might also be directly familiarized to their father through male

586 paternal care (Buchan, Alberts, Silk, \& Altmann, 2003; Charpentier, Van Horn, Altmann, \&

587 Alberts, 2008; Huchard et al., 2013; Langos, Kulik, Mundry, \& Widdig, 2013; Onyango,

588 Gesquiere, Altmann, \& Alberts, 2013). Evidence is building for male-infant associations

589 between father and offspring in several species (Table 8; Huchard et al., 2010), which in turn

590 allows for the familiarization of paternally related infants. Alternatively, paternal half-siblings

591 can get familiarized to each other directly if several females share the same preferred male

592 affiliation partner (Haunhorst et al., 2016; Seyfarth \& Cheney, 2012). In olive baboon immatures

593 (Papio anubis), bonds between paternal half-siblings are stronger when the father is present in

594 the group (Lynch et al., 2017), which highlights the importance of a shared association with a

595 common father for the development of a bias towards paternal kin. In our study, fathers

596 remained in the group for an average of 2.4 years ( 9 months -5.7 years) after the birth of two

597 paternal half-sisters, which would have given them ample time to get familiarized to each other

598 through the common father.

600 Another possibility is that individuals recognize their paternal kin through phenotype matching.

601 Several recent studies have shown that primates and other mammals are capable of using

602 acoustic, olfactory or visual cues to recognize their kin (Charpentier et al., 2017; Gilad,

603 Swaisgood, Owen, \& Zhou, 2016; Henkel \& Setchell, 2018; Mateo, 2017; Pfefferle, Ruiz-

604 Lambides, \& Widdig, 2014, 2015). Phenotype matching and familiarity are not mutually

605 exclusive mechanisms for kin recognition, and animals likely use multiple cues simultaneously

606 to discriminate kin from non-kin (Tang-Martinez, 2001; Widdig, 2007). 
608 Independent of the mechanism behind it, paternal kin recognition is based on proxies more

609 prone to error than the mother-mediated familiarity through which animals likely recognize

610 their maternal kin (Widdig, 2007). It is therefore not surprising that paternal kin biases are

611 usually less pronounced than biases towards maternal kin (Charpentier et al., 2012; Lynch et

612 al., 2017; Silk et al., 2006; Widdig et al., 2001). Contrary to our prediction, however, we found

613 no difference in bond strength between close maternal kin and paternal half-sisters. Three

614 factors might explain why paternal half-sisters formed bonds similar in strength as maternal

615 half-sisters and mother-daughter dyads: (1) paternal kin biases might be modulated by

616 maternal kin availability either if females form close compensatory bonds with their paternal

617 kin because too little close maternal kin is available (Silk et al., 2006; K. Smith et al., 2003), or if

618 females form bonds with paternal kin only if they are not saturated with close maternal kin; (2)

619 paternal kin might be as valuable as bonding partners as maternal kin are and/or (3) we lacked

620 the power to detect a difference in bond strength between maternal and paternal kin (sample

621 size of 59 adult females, 12 paternal half-sister dyads).

622

623 We found no evidence for an effect of the number of maternal kin available on the strength of

624 social bonds between paternal half-sisters or non-kin. In fact, the one female in our study that

625 had no (assigned) maternal kin available formed the weakest bond with her paternal half-sister

626 of all bonds between paternal half-sisters. Our results indicate that the close bonds we

627 observed between paternal kin were not compensating for a lack of close maternal kin. It is

628 important to note that to really assess whether females form compensatory bonds with

629 paternal kin would require monitoring how individuals adjust their social network after losing

630 or gaining close maternal kin. In chacma baboons (Papio ursinus), females increase the number 
631 of grooming partners after the loss of a close relative (Engh et al., 2006), and they might do so

632 by turning towards paternal kin. As we had only one dyad of paternal half-sisters where the number of close maternal kin changed within our study period, we could not look into how

634 females adjust to changes in partner availability in this study.

635

636 Paternal kin biases might also only develop if individuals do not saturate their social time on

637 close maternal kin. The fact that we found no effect of maternal kin availability on paternal kin

638 biases might imply that the number of close maternal kin (up to 5 maternal half-sisters, mother

639 and daughters for each female, probably more in the unassigned dyads) is not high enough to

640 saturate the social time available to the females in our study. It might be that maternal kin

641 availability only impacts paternal kin biases in extreme cases, where females have either

642 (almost) no close maternal kin available (K. Smith et al., 2003: similar bias towards paternal and

643 maternal kin), or where too many maternal kin are available (Perry et al., 2008: no paternal kin

644 bias), while in less extreme cases number of close maternal kin available or matriline size do

645 not affect paternal kin biases (this study; Charpentier et al., 2012; Cords et al., 2018).

646

647 Since maternal kin availability does not explain why we found similar biases towards paternal

648 and maternal kin, paternal kin could in fact be preferred to the same extent as maternal kin.

649 The social behaviours that we studied (proximity, body contact and grooming) are not costly

650 behaviours. Even if paternal kin are recognized less accurately than maternal kin, the cost of

651 investing any of those behaviours in a wrongly discriminated non-related individual would be

652 very small. Biases towards paternal kin in relatively low-cost behaviours might thus be more 

et al., 2006). Additionally, paternal kin might be valuable bonding partners, especially for lowerranking females, as they might have larger rank differences, in contrast to maternal kin who

657 are usually close in rank (Lynch et al., 2017). Social bonds in female Assamese macaques enhance feeding tolerance, so bonding with higher-ranking paternal half-sister might increase access to valuable resources (Heesen, Rogahn, Macdonald, Ostner, \& Schülke, 2014). In

660 mandrills (Mandrillus sphinx), juveniles form stronger bonds with their distant maternal kin

661 when they have less paternal kin available (Charpentier et al., 2012). In olive baboons,

662 immatures who had a father present in the group formed weaker bonds with their maternal

663 half-siblings (Lynch et al., 2017). It might thus be that animals have some flexibility in the choice

664 of their bonding partners, and that when they are able to discriminate paternal kin with some reliability, they might be as valuable partners as maternal kin.

666

667 On a broader level, our data contributes in differentiating between two perspectives on how 668 reproductive skew drives relatedness patterns, and how relatedness in turn drives social 669 structure. The first perspective is that in species with a high reproductive skew, most group 670 members are closely related. Selection will then favour indifferent tolerance towards all group 671 members for inclusive fitness benefits (Lukas \& Clutton-Brock, 2018). The second perspective 672 is that tolerance is reserved for kin only. In species with low male reproductive skew and short 673 male tenures few paternal kin are present in the group and all kin is maternal, yielding networks 674 of largely isolated matrilineal clusters. In contrast, in species with high paternity concentration 675 and/or long reproductive tenures many paternal kin might be present. Kin biases towards 676 paternal kin might form bridges of tolerance between matrilines that increase the overall 
677 tolerance and break up the substructure at the group level (Schülke \& Ostner, 2008). The crucial

678 difference between both perspectives is whether tolerance is differentiated or not. Here we

679 show that Assamese macaque females direct their affiliation selectively towards both paternal

680 and maternal kin over non-kin, which is in line with the second perspective.

681

682

683

684

685

686

687

688

689

690

691

692

693 


\begin{tabular}{|c|c|c|c|c|c|c|c|c|c|c|c|}
\hline Species (field site) & $\begin{array}{l}\text { Alpha male } \\
\text { paternity }\end{array}$ & $\begin{array}{l}\text { Alpha male } \\
\text { tenure }\end{array}$ & Subjects & $\begin{array}{l}\text { Maternal } \\
\text { kin bias }\end{array}$ & $\begin{array}{l}\text { Paternal } \\
\text { kin bias }\end{array}$ & $\begin{array}{l}\text { Dyads in same } \\
\text { age cohort } \\
\text { that are PK }\end{array}$ & $\begin{array}{l}\text { Dyads in diff. } \\
\text { age cohort } \\
\text { that are PK }\end{array}$ & $\begin{array}{l}\text { Effect of age } \\
\text { proximity? }\end{array}$ & $\begin{array}{c}\text { Effect of } \\
\text { maternal kin } \\
\text { availability? }\end{array}$ & $\begin{array}{l}\text { Father- } \\
\text { offspring } \\
\text { associations }\end{array}$ & References \\
\hline $\begin{array}{l}\text { Cebus capucinus } \\
\text { White-faced capuchin } \\
\text { (Lomas Barbudal, } \\
\text { Costa Rica) }\end{array}$ & $61.5-74 \%$ & $\begin{array}{l}\text { avg. } 5.4 \text { years } \\
\text { (1.3-14 years) }\end{array}$ & $12 \mathrm{AF}$ & $\begin{array}{l}\text { affiliation, } \\
\text { agonistic support }\end{array}$ & $\begin{array}{c}\text { no, but inbreeding } \\
\text { avoidance } \\
\text { father-daughter }\end{array}$ & $\begin{array}{c}55 \% \\
(\text { cohort }=2 y)\end{array}$ & $N A$ & not tested & not tested & $N A$ & $\begin{array}{l}{[1],[2],} \\
{[3],[4]}\end{array}$ \\
\hline $\begin{array}{c}\text { Cercopithecus mitis } \\
\text { Blue monkey } \\
\text { (Kakamega Forest, } \\
\text { Kenya) }\end{array}$ & $\begin{array}{l}61 \% \\
\text { (1 male } \\
\text { groups) }\end{array}$ & $\begin{array}{c}\text { avg. } 2.55 \mathrm{MaSe} \\
(1-7 \mathrm{MaSe})^{\dagger}\end{array}$ & $\begin{array}{c}78 \mathrm{AF} \\
\text { for } \mathrm{MK} \text { bias } \\
20 \mathrm{AF} \\
\text { for PK bias }\end{array}$ & $\begin{array}{l}\text { affiliation, } \\
\text { feeding tolerance }\end{array}$ & $\begin{array}{c}\text { affiliation } \\
\text { between adults, } \\
\text { not towards JUV }\end{array}$ & $\begin{array}{l}\text { predicted to } \\
\text { be } 37-52 \% \\
\text { (cohort = 1y) }\end{array}$ & $N A$ & no & no & $N A$ & $\begin{array}{c}{[5],[6],} \\
{[7]}\end{array}$ \\
\hline $\begin{array}{c}\text { Cercopithecus solatus } \\
\text { Sun-tailed monkey } \\
\text { (CIRMF, } \\
\text { Gabon) }\end{array}$ & $\begin{array}{l}100 \% \\
(1 \mathrm{male} \\
\text { group) }\end{array}$ & $\begin{array}{c}\text { avg. } 46.6 \text { months } \\
\text { (24-72 months) }\end{array}$ & $\begin{array}{l}10 \mathrm{AM}, \\
\mathrm{AF}, J U V\end{array}$ & $\begin{array}{c}\text { affiliation, } \\
\text { reduced aggression }\end{array}$ & no & $N A$ & $N A$ & not tested & not tested & $N A$ & [8], [9] \\
\hline $\begin{array}{c}\text { Colobus vellerosus } \\
\text { Ursine colobus monkey } \\
\text { (Boabeng-Fiema, } \\
\text { Ghana) }\end{array}$ & $87.5 \%{ }^{\ddagger}$ & $\begin{array}{l}\quad N A \\
\text { male residency: } \\
\text { median } 2 \text { years } \\
\text { (1-60 months) }\end{array}$ & $38 \mathrm{AF}$ & affiliation & no & $\begin{array}{c}50 \% \text { of INF } \\
(\text { cohort }=2 y)^{\ddagger}\end{array}$ & $18 \%$ of INF & no & not tested & $N A$ & {$[10],[11]$} \\
\hline $\begin{array}{l}\text { Crocuta crocuta } \\
\text { Spotted hyena } \\
\text { (Masai Mara, } \\
\text { Kenya) }\end{array}$ & $5 \%$ & $\begin{array}{l}\text { avg. } 9.2 \text { months } \\
\text { (1-34 months) } \\
\text { non-seasonal } \\
\text { breeding }\end{array}$ & $\begin{array}{l}80 \mathrm{AM}, \\
\mathrm{AF}, J U V\end{array}$ & $\begin{array}{c}\text { affiliation, } \\
\text { agonistic support }\end{array}$ & $\begin{array}{l}\text { feeding tolerance, } \\
\text { agonistic support, } \\
\text { reduced aggression }\end{array}$ & \multicolumn{2}{|c|}{$\begin{array}{l}\text { 89.7\% PS born } \\
\text { in different years }\end{array}$} & $\begin{array}{c}\text { affiliation litter MS } \\
>\text { non-litter MS }\end{array}$ & NA & $\begin{array}{l}\text { cubs associate } \\
\text { more with sire } \\
\text { than with non- } \\
\text { sire }\end{array}$ & $\begin{array}{c}\text { [12], [13] } \\
{[14]}\end{array}$ \\
\hline $\begin{array}{c}\text { Macaca assamensis } \\
\text { Assamese macaque } \\
\text { (Phu Khieo, } \\
\text { Thailand) }\end{array}$ & $29 \%$ & $\begin{array}{l}\text { avg. } 18.3 \text { months } \\
\text { (2-34 months) }\end{array}$ & $59 \mathrm{AF}$ & affiliation, & affiliation & $\begin{array}{c}4.8 \% \\
\text { (cohort = 1y) }\end{array}$ & $2.1 \%$ & no & no & $\begin{array}{l}\text { sires associate } \\
\text { more with } \\
\text { offspring } \\
\text { than non-sires }\end{array}$ & $\begin{array}{c}\text { this study, } \\
\text { [15], [16], } \\
\text { [17] }\end{array}$ \\
\hline
\end{tabular}




\begin{tabular}{|c|c|c|c|c|c|c|c|c|c|c|c|}
\hline $\begin{array}{c}\text { Macaca mulatta } \\
\text { Rhesus macaque } \\
\text { (Cayo Santiago, } \\
\text { Puerto Rico) }\end{array}$ & $\begin{array}{c}0 \\
(24 \% \text { top sire })\end{array}$ & \begin{tabular}{|c|} 
NA \\
male residency: \\
avg. 23.9 months \\
(16-33.5 months)
\end{tabular} & $34 \mathrm{AF}$ & $\begin{array}{l}\text { affiliation, } \\
\text { agonistic support, } \\
\text { refrain from } \\
\text { harming }\end{array}$ & $\begin{array}{l}\text { affiliation, } \\
\text { refrain from } \\
\text { harming }\end{array}$ & $\begin{array}{c}12.7 \\
(\text { cohort }=0.5 y)^{\S}\end{array}$ & $3.9 \%$ & \begin{tabular}{|c|} 
PS \& NK peer \\
$>$ non-peer, \\
bond strength \\
decreased for larger \\
age differences
\end{tabular} & not tested & $\begin{array}{c}\text { sires affiliate } \\
\text { more with } \\
\text { offspring } \\
\text { than non-sires }\end{array}$ & $\begin{array}{l}\text { [18], [19], } \\
{[20],[21],} \\
{[22],[23]}\end{array}$ \\
\hline $\begin{array}{c}\text { Mandrillus sphinx } \\
\text { Mandrill } \\
\text { (CIRMF, } \\
\text { Gabon) } \\
\end{array}$ & $69 \%-76.2 \%$ & \begin{tabular}{|c|} 
avg. 1.6 years \\
$(0.2-3.5$ years $)$ \\
for studied group
\end{tabular} & 22-30 JUV & $\begin{array}{c}\text { affiliation } \\
\text { towards adults } \\
\text { \& between JUV }\end{array}$ & $\begin{array}{c}\text { affiliation } \\
\text { towards adults, } \\
\text { not between JUV }\end{array}$ & NA & $N A$ & no & $\begin{array}{c}\text { no, but JUV } \\
\text { with less PS } \\
\text { affiliate more } \\
\text { with MK } \\
\end{array}$ & NA & $\begin{array}{l}\text { [24], [25], } \\
{[26],[27]}\end{array}$ \\
\hline \multirow{2}{*}{$\begin{array}{c}\text { Pan troglodytes } \\
\text { schweinfurthii } \\
\text { Chimpanzee } \\
\text { (Ngogo, } \\
\text { Uganda) }\end{array}$} & \multirow{2}{*}{$30.8-46.5 \%$ ? } & \multirow{3}{*}{$\begin{array}{l}\text { avg. } 5.4 \text { years } \\
\text { (1.9-8.7 years) } \\
\text { in Gombe, } \\
\text { Tanzania }\end{array}$} & $41 \mathrm{AM}$ & $\begin{array}{l}\text { affiliation, } \\
\text { agonistic support, } \\
\text { meat sharing }\end{array}$ & no & $\begin{array}{c}5.1 \% \\
\text { (cohort = 5y) }\end{array}$ & $2 \%$ & not tested & no & \multirow{3}{*}{$\begin{array}{l}\text { sire spends } \\
\text { more time } \\
\text { playing with } \\
\text { offspring than } \\
\text { with other } \\
\text { infants }\end{array}$} & $\begin{array}{l}\text { [28], [29], } \\
{[30],[31],} \\
{[32],[33]}\end{array}$ \\
\hline & & & $35 \mathrm{AM}$ & $\begin{array}{l}\text { grooming } \\
\text { equitability, } \\
\text { bond stability }\end{array}$ & no & NA & $N A$ & no & not tested & & $\begin{array}{l}\text { [29], [30], } \\
{[31],[32],} \\
{[33],[34]}\end{array}$ \\
\hline $\begin{array}{l}\text { Pan troglodytes verus } \\
\text { Chimpanzee } \\
\text { (Taï, } \\
\text { Ivory Coast) }\end{array}$ & $46.5 \%$ & & 4-10 INF & affiliation & trend for affiliation & NA & $N A$ & not tested & not tested & & $\begin{array}{c}\text { [29], [30], } \\
{[33]}\end{array}$ \\
\hline \multirow{2}{*}{$\begin{array}{l}\text { Papio cynocephalus } \\
\text { Yellow baboon } \\
\text { (Amboseli, } \\
\text { Kenya) }\end{array}$} & \multirow[b]{2}{*}{$34 \%$} & \multirow{2}{*}{$\begin{array}{c}\text { avg. } 8 \text { months } \\
(1.3-26.5 \text { months })\end{array}$} & $118 \mathrm{AF}$ & affiliation & affiliation & $\begin{array}{c}38 \% \\
(\text { cohort = 1y) }\end{array}$ & $7 \%$ & $\begin{array}{c}\text { PS \& NK peer } \\
\text { > non-peer, } \\
\text { bond strength } \\
\text { decreased for larger } \\
\text { age differences } \\
\end{array}$ & yes & \multirow{2}{*}{\begin{tabular}{|c|} 
sires selectively \\
support \\
offspring \\
in conflicts
\end{tabular}} & $\begin{array}{l}\text { [35], [36], } \\
\text { [37], [38] }\end{array}$ \\
\hline & & & $29 \mathrm{AF}$ & $\begin{array}{l}\text { affiliation, } \\
\text { feeding tolerance }\end{array}$ & affiliation & NA & $N A$ & $\begin{array}{c}\text { peer }>\text { non-peer, } \\
\text { but PS peer } \\
=\text { PS non-peer, } \\
\text { bond strength } \\
\text { decreased for larger } \\
\text { age differences } \\
\end{array}$ & $\begin{array}{l}\text { suggested, } \\
\text { not tested }\end{array}$ & & $\begin{array}{l}\text { [36], [37], } \\
{[38],[39]}\end{array}$ \\
\hline $\begin{array}{l}\text { Papio anubis } \\
\text { Olive baboon } \\
\text { (Laikipia, } \\
\text { Kenya) }\end{array}$ & $N A$ & $N A$ & $39 \mathrm{IMM}$ & affiliation & affiliation & NA & $N A$ & $\begin{array}{c}\text { bond strength } \\
\text { decreased for larger } \\
\text { age differences }\end{array}$ & no & $\begin{array}{c}\text { INF affiliate } \\
\text { more with sire } \\
\text { than non-sires }\end{array}$ & [40] \\
\hline
\end{tabular}


696

697

698

699

700

701

AF: adult females, AM: adult males, JUV: juveniles, INF: infants, IMM: immatures, MK: maternal kin, PK: paternal kin, PS: paternal half-siblings, MS: maternal half-siblings,

peers: individuals born in the same age cohort, litter: littermate (same age \& same den), non-litter: non-littermate (different age \& different den)

+ MaSe $=$ mating season $(1 /$ year $)$

₹ for the one multimale group in the study, all females in one-male groups were PS

$\S 74 \%$ individuals have PS of same age

ๆ 30.8 (Budongo, Uganda); 35.7\% (Gombe, Tanzania); 46.5\% (Taï, Ivory Coast)

[1] Perry et al., 2008; [2] Muniz et al., 2006; [3] Muniz et al., 2010; [4] Perry, 2012

[5] Cords et al., 2018; [6] Cords \& Nikitopoulos, 2015 ; [7] Roberts, Nikitopoulos, \& Cords, 2014

[8] Charpentier, Deubel, \& Peignot, 2008 ; [9] Charpentier, Hossaert-McKey, Wickings, \& Peignot, 2005

[10] Wikberg et al., 2014; [11] Wikberg, Sicotte, Campos, \& Ting, 2012

[12] Wahaj et al., 2004; [13] Engh et al., 2002; [14] Van Horn, Wahaj, \& Holekamp, 2004

[15] Minge, Berghänel, Schülke, \& Ostner, 2016; [16] Ostner et al., 2013; [17] Sukmak et al., 2014

[18] Widdig et al., 2001; [19] Widdig et al., 2004; [20] Widdig et al., 2006; [21] Widdig, 2013; [22] Langos et al., 2013; [23] Manson, 1995

[24] Charpentier et al., 2012; [25] Charpentier et al., 2007; [26] Charpentier, Peignot, et al., 2005; [27] Setchell, Charpentier, \& Wickings, 2005

[28] Langergraber et al., 2007; [29] Boesch, Kohou, Nene, \& Vigilant, 2006; [30] Bray, Pusey, \& Gilby, 2016; [31] Constable, Ashley, Goodall, \& Pusey, 2001; [32] Newton-Fisher, Thompson, Reynolds, Boesch, \& Vigilant, 2010; ; [33] Lehmann, Fickenscher, \& Boesch, 2006 ; [34] Mitani, 2009

[35] Silk et al., 2006; [36] Alberts, Buchan, \& Altmann, 2006; [37] Alberts, Watts, \& Altmann, 2003; [38] Buchan et al., 2003; [39] Smith et al., 2003

[40] Lynch et al., 2017 


\section{ACKNOWLEDGEMENTS}

720 We thank the National Research Council of Thailand and the Department of National Parks,

721 Wildife and Plant Conservation for permission to conduct this study and for all the support granted. We are grateful to J. Prabnasuk, K. Nitaya T. Wonsnak, M. Pongjantarasatien and K. cooperation over the years and permission to carry out this study. We thank A. Koenig and C. Borries, who established the field site. Special thanks go to S. Jumrudwong, W. Nueorngshiyos,

We also thank C. Schwarz for her support in the genetics lab, R. Mundry for valuable statistical advice, A.V. Rincon for help in using R, and G. Dezecache for useful comments on the manuscript. We thank the members of the research training group 'Understanding Social 254142454 / GRK 2070.

\section{AUTHOR CONTRIBUTIONS}

735 J.O. and O.S. designed the research. D.D.M. performed the field research and the lab work, and did the data analyses. J.O. and O.S. supervised the behavioural data collection and analysis, and C.R. advised and supervised the lab work. All authors discussed the results, and D.D.M. took the lead in writing the manuscript. All authors provided critical feedback and helped shape the research, analysis and manuscript. 
bioRxiv preprint doi: https://doi.org/10.1101/714253; this version posted July 26, 2019. The copyright holder for this preprint (which was not certified by peer review) is the author/funder, who has granted bioRxiv a license to display the preprint in perpetuity. It is made available under aCC-BY-NC-ND 4.0 International license.

\section{REFERENCES}

Adamack, A. T., \& Gruber, B. (2014). PopGenReport: Simplifying basic population genetic analyses in R. Methods in Ecology and Evolution, 5(4), 384-387. doi:10.1111/2041210x.12158

Alberts, S. C., Buchan, J. C., \& Altmann, J. (2006). Sexual selection in wild baboons: From mating opportunities to paternity success. Animal Behaviour, 72(5), 1177-1196. doi:10.1016/j.anbehav.2006.05.001

Alberts, S. C., Watts, H. E., \& Altmann, J. (2003). Queuing and queue-jumping: Long-term patterns of reproductive skew in male savannah baboons, Papio cynocephalus. Animal Behaviour, 65(4), 821-840. doi:10.1006/anbe.2003.2106

Altmann, J. (1979). Age cohorts as paternal sibships. Behavioral Ecology and Sociobiology, 6(2), 161-164. doi:10.1007/BF00292563

Arandjelovic, M., Guschanski, K., Schubert, G., Harris, T. R., Thalmann, O., Siedel, H., \& Vigilant, L. (2009). Two-step multiplex polymerase chain reaction improves the speed and accuracy of genotyping using DNA from noninvasive and museum samples. Molecular Ecology Resources, 9(1), 28-36. doi:10.1111/j.1755-0998.2008.02387.x

Archie, E. A., Moss, C. J., \& Alberts, S. C. (2006). The ties that bind: Genetic relatedness predicts the fission and fusion of social groups in wild African elephants. Proceedings of the Royal Society B, 273(1586), 513-522. doi:10.1098/rspb.2005.3361

Baniel, A., Cowlishaw, G., \& Huchard, E. (2016). Stability and strength of male-female associations in a promiscuous primate society. Behavioral Ecology and Sociobiology, 70(5), 761-775. doi:10.1007/s00265-016-2100-8

Bates, D., Mächler, M., Bolker, B., \& Walker, S. (2015). Fitting linear mixed-effects models using Ime4. Journal of Statistical Software, 67, 1-48.

Berman, C. M. (2015). Kin-directed behavior in primates. In S. R. Kosslyn S. (Ed.), Emerging Trends in the Social and Behavioral Sciences: An Interdisciplinary, Searchable, and Linkable Resource (pp. 1-16): John Wiley \& Sons.

Boesch, C., Kohou, G., Nene, H., \& Vigilant, L. (2006). Male competition and paternity in wild chimpanzees of the Tai forest. American Journal of Physical Anthropology, 130(1), 103115. doi:10.1002/ajpa.20341

Borries, C., Larney, E., Kreetiyutanont, K., \& Koenig, A. (2002). The diurnal primate community in a dry evergreen forest in Phu Khieo Wildlife Sanctuary, Northeast Thailand. Natural History Bulletin of the Siam Society, 50(1), 75-88.

Bray, J., Pusey, A. E., \& Gilby, I. C. (2016). Incomplete control and concessions explain mating skew in male chimpanzees. Proceedings of the Royal Society B, 283(1842), 20162071. doi:10.1098/rspb.2016.2071

Brent, L. J., Chang, S. W., Gariépy, J. F., \& Platt, M. L. (2014). The neuroethology of friendship. Annals of the New York Academy of Sciences, 1316, 1-17. doi:10.1111/nyas.12315

Broad, K. D., Curley, J. P., \& Keverne, E. B. (2006). Mother-infant bonding and the evolution of mammalian social relationships. Philosophical Transactions of the Royal Society $B$, 361(1476), 2199-2214. doi:10.1098/rstb.2006.1940

Buchan, J. C., Alberts, S. C., Silk, J. B., \& Altmann, J. (2003). True paternal care in a multi-male primate society. Nature, 425(6954), 179-181. doi:10.1038/nature01866 
784

785

786

787

788

789

790

791

792

793

794

795

796

797

798

799

800

801

802

803

804

805

806

807

808

809

810

811

812

813

814

815

816

817

818

819

820

821

822

823

824

825

826

827

Cameron, E. Z., Setsaas, T. H., \& Linklater, W. L. (2009). Social bonds between unrelated females increase reproductive success in feral horses. Proceedings of the National Academy of Sciences of the United States of America, 106(33), 13850-13853. doi:10.1073/pnas.0900639106

Candiotti, A., Coye, C., Ouattara, K., Petit, E. J., Vallet, D., Zuberbühler, K., \& Lemasson, A. (2015). Female bonds and kinship in forest guenons. International Journal of Primatology, 36(2), 332-352. doi:10.1007/s10764-015-9829-1

Carter, K. D., Seddon, J. M., Frère, C. H., Carter, J. K., \& Goldizen, A. W. (2013). Fission-fusion dynamics in wild giraffes may be driven by kinship, spatial overlap and individual social preferences. Animal Behaviour, 85(2), 385-394. doi:10.1016/j.anbehav.2012.11.011

Chapais, B., \& Berman, C. M. (2004). Kinship and behavior in primates. Oxford: Oxford University Press.

Charpentier, M. J. E., Deubel, D., \& Peignot, P. (2008). Relatedness and social behaviors in Cercopithecus solatus. International Journal of Primatology, 29(2), 487-495. doi:10.1007/s10764-008-9246-9

Charpentier, M. J. E., Harté, M., Ngoubangoye, B., Herbert, A., Kappeler, P. M., \& Manser, M. (2017). Visual discrimination of kin in mandrills. Ethology, 123(3), 251-259. doi:10.1111/eth.12596

Charpentier, M. J. E., Hossaert-McKey, M., Wickings, E. J., \& Peignot, P. (2005). Consequences of a one-male harem reproductive system and inbreeding in a captive group of Cercopithecus solatus. International Journal of Primatology, 26(3), 697-710. doi:10.1007/s10764-005-4375-x

Charpentier, M. J. E., Huchard, E., Widdig, A., Gimenez, O., Sallé, B., Kappeler, P. M., . . Fusani, L. (2012). Distribution of affiliative behavior across kin classes and their fitness consequences in mandrills. Ethology, 118(12), 1198-1207. doi:10.1111/eth.12026

Charpentier, M. J. E., Peignot, P., Hossaert-McKey, M., Gimenez, O., Setchell, J. M., \& Wickings, E. J. (2005). Constraints on control: Factors influencing reproductive success in male mandrills (Mandrillus sphinx). Behavioral Ecology, 16(3), 614-623. doi:10.1093/beheco/ari034

Charpentier, M. J. E., Peignot, P., Hossaert-McKey, M., \& Wickings, E. J. (2007). Kin discrimination in juvenile mandrills, Mandrillus sphinx. Animal Behaviour, 73(1), 37-45. doi:10.1016/j.anbehav.2006.02.026

Charpentier, M. J. E., Van Horn, R. C., Altmann, J., \& Alberts, S. C. (2008). Paternal effects on offspring fitness in a multimale primate society. Proceedings of the National Academy of Sciences of the United States of America, 105(6), 1988-1992. doi:10.1073/pnas.0711219105

Clutton-Brock, T. (2009). Cooperation between non-kin in animal societies. Nature, 462(7269), 51-55. doi:10.1038/nature08366

Constable, J. L., Ashley, M. V., Goodall, J., \& Pusey, A. E. (2001). Noninvasive paternity assignment in Gombe chimpanzees. Molecular Ecology, 10(5), 1279-1300. doi:10.1046/j.1365-294x.2001.01262.x

Cords, M., Minich, T., Roberts, S. J., \& Sleator, C. (2018). Evidence for paternal kin bias in the social affiliation of adult female blue monkeys. American Journal of Primatology, 80(5). doi:10.1002/ajp.22761 
828

829

830

831

832

833

834

835

836

837

838

839

840

841

842

843

844

845

846

847

848

849

850

851

852

853

854

855

856

857

858

859

860

861

862

863

864

865

866

867

868

869

870

Cords, M., \& Nikitopoulos, E. (2015). Maternal kin bias in affiliative behavior among wild adult female blue monkeys. American Journal of Primatology, 77(1), 109-123. doi:10.1002/ajp.22315

Diaz-Aguirre, F., Parra, G. J., Passadore, C., \& Möller, L. (2018). Kinship influences social bonds among male southern Australian bottlenose dolphins (Tursiops cf. australis). Behavioral Ecology and Sociobiology, 72(12). doi:10.1007/s00265-018-2621-4

Engelhardt, A., Muniz, L., Perwitasari-Farajallah, D., \& Widdig, A. (2017). Highly polymorphic microsatellite markers for the assessment of male reproductive skew and genetic variation in critically endangered crested macaques (Macaca nigra). International Journal of Primatology, 38(4), 672-691. doi:10.1007/s10764-017-9973-x

Engh, A. L., Beehner, J. C., Bergman, T. J., Whitten, P. L., Hoffmeier, R. R., Seyfarth, R. M., \& Cheney, D. L. (2006). Behavioural and hormonal responses to predation in female chacma baboons (Papio hamadryas ursinus). Proceedings of the Royal Society B, 273(1587), 707-712. doi:10.1098/rspb.2005.3378

Fox, J., \& Weisberg, S. (2011). Multivariate linear models in R. An R Companion to Applied Regression. Los Angeles: Thousand Oaks.

Fürtbauer, I., Schülke, O., Heistermann, M., \& Ostner, J. (2010). Reproductive and life history parameters of wild female Macaca assamensis. International Journal of Primatology, 31(4), 501-517. doi:10.1007/s10764-010-9409-3

Gilad, O., Swaisgood, R. R., Owen, M. A., \& Zhou, X. (2016). Giant pandas use odor cues to discriminate kin from nonkin. Current Zoology, 62(4), 333-336. doi:10.1093/cz/zow025

Greenwood, P. J. (1980). Mating systems, philopatry and dispersal in birds and mammals. Animal Behaviour, 28(4), 1140-1162. doi:10.1016/S0003-3472(80)80103-5

Hamilton, W. D. (1964). The genetical evolution of social behaviour. I. Journal of Theoretical Biology, 7(1), 1-16. doi:10.1016/0022-5193(64)90038-4

Haunhorst, C. B., Schülke, O., \& Ostner, J. (2016). Opposite-sex social bonding in wild Assamese macaques. American Journal of Primatology, 78(8), 872-882. doi:10.1002/ajp.22554

Heesen, M., Rogahn, S., Macdonald, S., Ostner, J., \& Schülke, O. (2014). Predictors of foodrelated aggression in wild Assamese macaques and the role of conflict avoidance. Behavioral Ecology and Sociobiology, 68(11), 1829-1841. doi:10.1007/s00265-0141792-x

Henkel, S., \& Setchell, J. M. (2018). Group and kin recognition via olfactory cues in chimpanzees (Pan troglodytes). Proceedings of the Royal Society B, 285(1889), 20181527. doi:10.1098/rspb.2018.1527

Hinde, R. A. (1976). Interactions, relationships and social structure. Man, 11, 1-17. doi:10.2307/2800384

Hothorn, T., Bretz, F., \& Westfall, P. (2008). Simultaneous inference in general parametric models. Biometrical journal, 50(3), 346-363. doi:10.1002/bimj.200810425.

Huchard, E., Alvergne, A., Féjan, D., Knapp, L. A., Cowlishaw, G., \& Raymond, M. (2010). More than friends? Behavioural and genetic aspects of heterosexual associations in wild chacma baboons. Behavioral Ecology and Sociobiology, 64(5), 769-781. doi:10.1007/s00265-009-0894-3 
871

872

873

874

875

876

877

878

879

880

881

882

883

884

885

886

887

888

889

890

891

892

893

894

895

896

897

898

899

900

901

902

903

904

905

906

907

908

909

910

911

912

913

914

Huchard, E., Charpentier, M. J., Marshall, H., King, A. J., Knapp, L. A., \& Cowlishaw, G. (2013). Paternal effects on access to resources in a promiscuous primate society. Behavioral Ecology, 24(1), 229-236. doi:10.1093/beheco/ars158

Jennions, M. D., \& Petrie, M. (2000). Why do females mate multiply? A review of the genetic benefits. Biological Reviews, 75(1), 21-64. doi:10.1017/S0006323199005423

Jones, O. R., \& Wang, J. (2010). COLONY: A program for parentage and sibship inference from multilocus genotype data. Molecular Ecology Resources, 10(3), 551-555. doi:10.1111/j.1755-0998.2009.02787.x

Kalbitzer, U., Bergstrom, M. L., Carnegie, S. D., Wikberg, E. C., Kawamura, S., Campos, F. A., . . . Fedigan, L. M. (2017). Female sociality and sexual conflict shape offspring survival in a Neotropical primate. Proceedings of the National Academy of Sciences of the United States of America, 114(8), 1892-1897. doi:10.1073/pnas.1608625114

Kalinowski, S. T., Taper, M. L., \& Marshall, T. C. (2007). Revising how the computer program CERVUS accommodates genotyping error increases success in paternity assignment. Molecular Ecology, 16(5), 1099-1106. doi:10.1111/j.1365-294X.2007.03089.x

Kopps, A. M., Kang, J., Sherwin, W. B., \& Palsboll, P. J. (2015). How well do molecular and pedigree relatedness correspond, in populations with diverse mating systems, and various types and quantities of molecular and demographic data? G3: Genes, Genomes, Genetics, 5(9), 1815-1826. doi:10.1534/g3.115.019323

Kummer, H. (1978). On the value of social relationships to nonhuman primates: A heuristic scheme. Social Science Information, 17(4-5), 687-705. doi:10.1177/053901847801700418

Langergraber, K. E. (2012). Cooperation among kin. In J. C. Mitani, Call, J., Kappeler, P. M., Palombit, R. A., \& Silk, J. B. (Ed.), The evolution of primate societies (pp. 491-513): University of Chicago Press.

Langergraber, K. E., Mitani, J. C., \& Vigilant, L. (2007). The limited impact of kinship on cooperation in wild chimpanzees. Proceedings of the National Academy of Sciences of the United States of America, 104(19), 7786-7790. doi:10.1073/pnas.0611449104

Langos, D., Kulik, L., Mundry, R., \& Widdig, A. (2013). The impact of paternity on male-infant association in a primate with low paternity certainty. Molecular Ecology, 22(13), 36383651. doi:10.1111/mec.12328

Lehmann, J., Fickenscher, G., \& Boesch, C. (2006). Kin biased investment in wild chimpanzees. Behaviour, 143(8), 931-956. doi:10.1163/156853906778623635

Lemasson, A., Palombit, R. A., \& Jubin, R. (2008). Friendships between males and lactating females in a free-ranging group of olive baboons (Papio hamadryas anubis): Evidence from playback experiments. Behavioral Ecology and Sociobiology, 62(6), 1027-1035. doi:10.1007/s00265-007-0530-z

Lukas, D., \& Clutton-Brock, T. (2018). Social complexity and kinship in animal societies. Ecology Letters, 21(8), 1129-1134. doi:10.1111/ele.13079

Lynch, E. C., Di Fiore, A., Lynch, R. F., \& Palombit, R. A. (2017). Fathers enhance social bonds among paternal half-siblings in immature olive baboons (Papio hamadryas anubis). Behavioral Ecology and Sociobiology, 71(8). doi:10.1007/s00265-017-2336-y

Manson, J. H. (1995). Do female rhesus macaques choose novel males? American Journal of Primatology, 37(4), 285-296. doi:10.1002/ajp.1350370403 
915

916

917

918

919

920

921

922

923

924

925

926

927

928

929

930

931

932

933

934

935

936

937

938

939

940

941

942

943

944

945

946

947

948

949

950

951

952

953

954

955

956

957

958

959

Mateo, J. M. (2017). The ontogeny of kin-recognition mechanisms in Belding's ground squirrels. Physiology \& Behavior, 173, 279-284. doi:10.1016/j.physbeh.2017.02.024

Minge, C., Berghanel, A., Schülke, O., \& Ostner, J. (2016). Patterns and consequences of maleinfant relationships in wild Assamese macaques (Macaca assamensis). International Journal of Primatology, 37, 350-370. doi:10.1007/s10764-016-9904-2

Mitani, J. C. (2009). Male chimpanzees form enduring and equitable social bonds. Animal Behaviour, 77(3), 633-640. doi:10.1016/j.anbehav.2008.11.021

Möller, L. M. (2012). Sociogenetic structure, kin associations and bonding in delphinids. Molecular Ecology, 21(3), 745-764. doi:10.1111/j.1365-294X.2011.05405.x

Moscovice, L. R., Di Fiore, A., Crockford, C., Kitchen, D. M., Wittig, R., Seyfarth, R. M., \& Cheney, D. L. (2010). Hedging their bets? Male and female chacma baboons form friendships based on likelihood of paternity. Animal Behaviour, 79(5), 1007-1015. doi:10.1016/j.anbehav.2010.01.013

Muniz, L., Perry, S., Manson, J. H., Gilkenson, H., Gros-Louis, J., \& Vigilant, L. (2006). Fatherdaughter inbreeding avoidance in a wild primate population. Current Biology, 16(5), R156-157. doi:10.1016/j.cub.2006.02.055

Muniz, L., Perry, S., Manson, J. H., Gilkenson, H., Gros-Louis, J., \& Vigilant, L. (2010). Male dominance and reproductive success in wild white-faced capuchins (Cebus capucinus) at Lomas Barbudal, Costa Rica. American Journal of Physical Anthropology, 72(12), 1118-1130. doi:10.1002/ajp.20876

Navidi, W., Arnheim, N., \& Waterman, M. S. (1992). A multiple-tubes approach for accurate genotyping of very small DNA samples by using PCR: Statistical considerations. American journal of human genetics, 50(2), 347-359.

Newton-Fisher, N. E., Thompson, M. E., Reynolds, V., Boesch, C., \& Vigilant, L. (2010). Paternity and social rank in wild chimpanzees (Pan troglodytes) from the Budongo Forest, Uganda. American Journal of Physical Anthropology, 142(3), 417-428. doi:10.1002/ajpa.21241

Nguyen, N., Van Horn, R. C., Alberts, S. C., \& Altmann, J. (2009). "Friendships" between new mothers and adult males: Adaptive benefits and determinants in wild baboons (Papio cynocephalus). Behavioral Ecology and Sociobiology, 63(9), 1331-1344. doi:10.1007/s00265-009-0786-6

Nsubuga, A. M., Robbins, M. M., Roeder, A. D., Morin, P. A., Boesch, C., \& Vigilant, L. (2004). Factors affecting the amount of genomic DNA extracted from ape faeces and the identification of an improved sample storage method. Molecular Ecology, 13(7), 20892094. doi:10.1111/j.1365-294X.2004.02207.x

Onyango, P. O., Gesquiere, L. R., Altmann, J., \& Alberts, S. C. (2013). Testosterone positively associated with both male mating effort and paternal behavior in Savanna baboons (Papio cynocephalus). Hormones and Behaviour, 63(3), 430-436. doi:10.1016/j.yhbeh.2012.11.014

Ostner, J., \& Schülke, O. (2018). Linking sociality to fitness in primates: A call for mechanisms. In M. Naguib, L. Barrett, S. D. Healy, J. Podos, L. W. Simmons, \& M. Zuk (Eds.), Advances in the Study of Behavior (Vol. 50, pp. 127-175): Academic Press.

Ostner, J., Vigilant, L., Bhagavatula, J., Franz, M., \& Schülke, O. (2013). Stable heterosexual associations in a promiscuous primate. Animal Behaviour, 86(3), 623-631. doi:10.1016/j.anbehav.2013.07.004 
960

961

962

963

964

965

966

967

968

969

970

971

972

973

974

975

976

977

978

979

980

981

982

983

984

985

986

987

988

989

990

991

992

993

994

995

996

997

998

999

1000

1001

1002

1003

Perry, S. (2012). The behavior of wild white-faced capuchins. In (Vol. 44, pp. 135-181).

Perry, S., Manson, J. H., Muniz, L., Gros-Louis, J., \& Vigilant, L. (2008). Kin-biased social behaviour in wild adult female white-faced capuchins, Cebus capucinus. Animal Behaviour, 76(1), 187-199. doi:10.1016/j.anbehav.2008.01.020

Pew, J., Muir, P. H., Wang, J., \& Frasier, T. R. (2015). related: An R package for analysing pairwise relatedness from codominant molecular markers. Molecular Ecology Resources, 15(3), 557-561. doi:10.1111/1755-0998.12323

Pfefferle, D., Ruiz-Lambides, A. V., \& Widdig, A. (2014). Female rhesus macaques discriminate unfamiliar paternal sisters in playback experiments: Support for acoustic phenotype matching. Proceedings of the Royal Society B, 281(1774), 20131628. doi:10.1098/rspb.2013.1628

Pfefferle, D., Ruiz-Lambides, A. V., \& Widdig, A. (2015). Male rhesus macaques use vocalizations to distinguish female maternal, but not paternal, kin from non-kin. Behavioral Ecology and Sociobiology, 69(10), 1677-1686. doi:10.1007/s00265-0151979-9

R Development Core Team. (2018). R: A language and environment for statistical computing. Vienna, Austria: R Foundation for Statistical Computing.

Roberts, S., Nikitopoulos, E., \& Cords, M. (2014). Factors affecting low resident male siring success in one-male groups of blue monkeys. Behavioral Ecology, 25(4), 852-861. doi:10.1093/beheco/aru060

Rossiter, S. J., Jones, G., Ransome, R. D., \& Barratt, E. M. (2002). Relatedness structure and kin-biased foraging in the greater horseshoe bat (Rhinolophus ferrumequinum). Behavioral Ecology and Sociobiology, 51(6), 510-518. doi:10.1007/s00265-002-0467-1

RStudio Team. (2016). RStudio: Integrated development environment for R. Boston, MA: RStudio, Inc. Retrieved from http://www.rstudio.com

Schülke, O., \& Ostner, J. (2008). Male reproductive skew, paternal relatedness, and female social relationships. American Journal of Primatology, 70(7), 1-4. doi:10.1002/ajp.20546

Schülke, O., Pesek, D., Whitman, B. J., \& Ostner, J. (2011). Ecology of Assamese macaques (Macaca assamensis) at Phu Khieo Wildlife Sanctuary, Thailand. Journal of Wildlife in Thailand, 18(1), 1-15.

Setchell, J. M., Charpentier, M. J. E., \& Wickings, E. J. (2005). Mate guarding and paternity in mandrills: Factors influencing alpha male monopoly. Animal Behaviour, 70(5), 11051120. doi:10.1016/j.anbehav.2005.02.021

Seyfarth, R. M., \& Cheney, D. L. (2012). The evolutionary origins of friendship. Annual Review of Psychology, 63, 153-177. doi:10.1146/annurev-psych-120710-100337

Silk, J. B. (2009). Nepotistic cooperation in non-human primate groups. Philosophical Transactions of the Royal Society B, 364(1533), 3243-3254. doi:10.1098/rstb.2009.0118

Silk, J. B., Altmann, J., \& Alberts, S. C. (2006). Social relationships among adult female baboons (Papio cynocephalus) I. Variation in the strength of social bonds. Behavioral Ecology and Sociobiology, 61(2), 183-195. doi:10.1007/s00265-006-0249-2

Silk, J. B., Cheney, D., \& Seyfarth, R. (2013). A practical guide to the study of social relationships. Evolutionary Anthropology, 22(5), 213-225. doi:10.1002/evan.21367 
1004

1005

1006

1007

1008

1009

1010

1011

1012

1013

1014

1015

1016

1017

1018

1019

1020

1021

1022

1023

1024

1025

1026

1027

1028

1029

1030

1031

1032

1033

1034

1035

1036

1037

1038

1039

1040

1041

1042

1043

1044

1045

1046

1047

1048

Smith, J. E. (2014). Hamilton's legacy: Kinship, cooperation and social tolerance in mammalian groups. Animal Behaviour, 92, 291-304. doi:10.1016/j.anbehav.2014.02.029

Smith, J. E., Van Horn, R. C., Powning, K. S., Cole, A. R., Graham, K. E., Memenis, S. K., \& Holekamp, K. E. (2010). Evolutionary forces favoring intragroup coalitions among spotted hyenas and other animals. Behavioral Ecology, 21(2), 284-303. doi:10.1093/beheco/arp181

Smith, K., Alberts, S. C., \& Altmann, J. (2003). Wild female baboons bias their social behaviour towards paternal half-sisters. Proceedings of the Royal Society B, 270(1514), 503-510. doi:10.1098/rspb.2002.2277

Strier, K. B. (2004). Patrilineal kinship and primate behavior. In B. Chapais \& C. M. Berman (Eds.), Kinship and behavior in primates (pp. 177-199). Oxford: Oxford University Press.

Sukmak, M., Wajjwalku, W., Ostner, J., \& Schülke, O. (2014). Dominance rank, female reproductive synchrony, and male reproductive skew in wild Assamese macaques. Behavioral Ecology and Sociobiology, 68(7), 1097-1108. doi:10.1007/s00265-0141721-z

Taberlet, P., Griffin, S., Goossens, B., Questiau, S., Manceau, V., Escaravage, N., . . Bouvet, J. (1996). Reliable genotyping of samples with very low DNA quantities using PCR. Nucleic acids research, 24(16), 3189-3194. doi:10.1093/nar/24.16.3189

Tang-Martinez, Z. (2001). The mechanisms of kin discrimination and the evolution of kin recognition in vertebrates: A critical re-evaluation. Behavioural Processes, 53(1-2), 21 40. doi:10.1016/S0376-6357(00)00148-0

Thompson, N. A., \& Cords, M. (2018). Stronger social bonds do not always predict greater longevity in a gregarious primate. Ecology and Evolution, 8(3), 1604-1614. doi:10.1002/ece3.3781

Van Horn, R. C., Buchan, J. C., Altmann, J., \& Alberts, S. C. (2007). Divided destinies: Group choice by female savannah baboons during social group fission. Behavioral Ecology and Sociobiology, 61(12), 1823-1837. doi:10.1007/s00265-007-0415-1

Van Oosterhout, C., Hutchinson, W. F., Wills, D. P. M., \& Shipley, P. (2004). MICRO-CHECKER: Software for identifying and correcting genotyping errors in microsatellite data. Molecular Ecology Notes, 4(3), 535-538. doi:10.1111/j.1471-8286.2004.00684.x

Van Schaik, C. P., \& Kappeler, P. M. (1997). Infanticide risk and the evolution of male-female association in primates. Proceedings of the Royal Society B, 264(1388), 1687-1694. doi:10.1098/rspb.1997.0234

Wang, J. (2007). Triadic IBD coefficients and applications to estimating pairwise relatedness. Genetics Research, 89(3), 135-153. doi:10.1017/\$0016672307008798

Widdig, A. (2007). Paternal kin discrimination: The evidence and likely mechanisms. Biological Reviews, 82(2), 319-334. doi:10.1111/j.1469-185X.2007.00011.x

Widdig, A. (2013). The impact of male reproductive skew on kin structure and sociality in multi-male groups. Evolutionary Anthropology, 22(5), 239-250. doi:10.1002/evan.21366

Widdig, A., Bercovitch, F. B., Streich, W. J., Sauermann, U., Nurnberg, P., \& Krawczak, M. (2004). A longitudinal analysis of reproductive skew in male rhesus macaques. Proceedings of the Royal Society B, 271(1541), 819-826. doi:10.1098/rspb.2003.2666

Widdig, A., Nurnberg, P., Krawczak, M., Streich, W. J., \& Bercovitch, F. B. (2001). Paternal relatedness and age proximity regulate social relationships among adult female rhesus 
macaques. Proceedings of the National Academy of Sciences of the United States of America, 98(24), 13769-13773. doi:10.1073/pnas.241210198

Widdig, A., Streich, W. J., Nürnberg, P., Croucher, P. J. P., Bercovitch, F. B., \& Krawczak, M. (2006). Paternal kin bias in the agonistic interventions of adult female rhesus macaques (Macaca mulatta). Behavioral Ecology and Sociobiology, 61(2), 205-214. doi:10.1007/s00265-006-0251-8

Wikberg, E. C., Sicotte, P., Campos, F. A., \& Ting, N. (2012). Between-group variation in female dispersal, kin composition of groups, and proximity patterns in a black-and-white colobus monkey (Colobus vellerosus). PLoS One, 7(11), e48740. doi:10.1371/journal.pone.0048740 female social networks in black-and-white colobus monkeys (Colobus vellerosus). American Journal of Physical Anthropology, 153(3), 365-376. doi:10.1002/ajpa.22435

1064 In case of acceptance data will made accessible at a public repository (Dryad). 